\title{
Pendulum: distalização do molar com simplicidade na confecção e utilização
}

\author{
Mêrian Lucena M. LEIROS*, Leão Pereira PINTO**
}

\begin{abstract}
Resumo
Durante muito tempo, a correção da Classe II baseava-se no uso de ancoragem extrabucal. Atualmente, inúmeros dispositivos trazem a possibilidade de distalização dos molares permanentes superiores, dentre estes o aparelho pêndulo preconizado por Hilgers o qual requer um mínimo de cooperação do paciente, considerando-se que a falta de colaboração poderá levar ao fracasso o mais bem elaborado plano de tratamento. $\mathrm{O}$ objetivo deste trabalho é descrever as características, confecção e indicações do Pêndulo, contando com a ilustração de casos clínicos.
\end{abstract}

Palavras-chave: Tratamento ortodôntico. Distalização de molares. Pendulum de Hilgers. Classe II

\section{INTRODUÇÃO}

A estética facial sempre foi um aspecto muito importante para o ortodontista que busca de maneira incansável acompanhar os conceitos de beleza e até mesmo refazer os caminhos destas mudanças de acordo com cada época. Deste modo, esses conceitos influenciam de maneira positiva os seus planos de tratamento. Em uma breve retrospectiva, poderemos rever o clássico perfil grego (Fig. 1) considerado ideal na década de 30 ; no entanto, nos dias atuais, seria totalmente incompatível com os recentes conceitos de harmonia facial, onde o padrão de beleza valoriza lábios mais cheios e proeminentes, o que contribui para uma diminuição significativa no número de extrações dentárias, nos diferentes tipos de má oclusão. Além disso, os tratamentos com extrações não necessariamente ga- rantem a estabilidade do alinhamento dentário ${ }^{12}$.

Os aparelhos distalizadores, quando bem indicados, são excelentes alternativas na correção da Classe II ou na eliminação de apinhamentos ântero-superiores. Dentre os diversos tipos de utensílios intrabucais utilizados para distalização de molares, podemos destacar o Jones Jig, os magnetos e o pêndulo.

A utilização dos magnetos para distalização dos molares superiores foi descrita por Gianely et $\mathrm{al}^{7}$. Os resultados foram animadores, principalmente no que diz respeito à não necessidade de colaboração do paciente, a qual muitas vezes representa um problema nos tratamentos. Os autores observaram que oitenta por cento do espaço obtido representava exclusivamente distalização dos molares, com pouca perda de ancoragem, que

* Doutora em Ciências da Saúde-UFRN. Especialista em Ortodontia pela Academia Cearense de Odontologia. Ex-aluna do Programa de Excelência em Ortodontia. Vice-presidente da Sociedade de Ortodontia-RN.

** Professor Titular de Patologia Oral-UFRN. Professor Livre-Docente e Doutor em Patologia Oral-UFRN. Consultor Científico (AD-HOC) do CNPq e da CAPES. Professor orientador do Programa de Pós-Graduação em Ciências da Saúde-UFRN, nos níveis de Mestrado e Doutorado. Membro do Conselho Editorial da Revista Odonto-Ciência da PUC-RS. 
seria controlada por um botão de Nance cimentado nos primeiros pré-molares, estendendo-se até a região de incisivos.

Mensurando a distalização dos molares obtidas com magnetos, foi que Itoh et al. ${ }^{10}$, estudando dez casos de Classe II em pacientes com dentição mista, observaram que o movimento de distalização foi bastante rápido com ativações a cada duas semanas. Os resultados foram de $0.5 \mathrm{~mm}$ a $3.7 \mathrm{~mm}$ de distalização, com uma média de $2.1 \mathrm{~mm}$; observaram também inclinação distal dos molares de $7.4^{\circ}$ e inclinação dos dentes anteriores em torno de $3.8^{\circ}$. Os pacientes em estudo relataram desconforto apenas no início do tratamento.

Locatelli et al. ${ }^{13}$ utilizaram fio de níquel-titânio superelástico para movimento distal dos molares liberando força em torno de $100 \mathrm{~g}$ e relataram que a distalização era mais satisfatória quando os segundos molares ainda não haviam irrompido. Quando irrompidos, observaram maior perda de ancoragem.

Usando molas de Niti, Jones e White ${ }^{11}$ preconizaram o Jones Jig, dispositivo utilizado para distalização de molares. O Jones Jig dissipa uma força de 70 a $75 \mathrm{~g}$ e apresenta a vantagem de distalização molar uni ou bilateralmente, além de poder ser utilizado com os segundos molares irrompidos ou não, em dentadura mista ou permanente. Os autores relataram rapidez na correção da Classe II; no entanto, durante o movimento de distalização dos molares ocorria inclinação distal da coroa, além disso, quando os segundos molares estavam presentes, ocorria uma maior perda de ancoragem.

Um novo mecanismo foi idealizado por Hilgers $^{9}$, com a finalidade de promover a distalização dos primeiros molares e que não dependeria da total colaboração do paciente ao seu uso. O aparelho apresentava um botão de resina acrílica no palato para ancoragem e molas TMA que liberavam forças moderadas e contínuas, e obtiveram 2 a $6 \mathrm{~mm}$ como média de movimentação distal. Se uma expansão fosse necessária, um parafuso deveria ser acrescido ao aparelho que passaria a ser chamado de Pendex.
Avaliando a eficiência dos magnetos e molas de Níquel Titânio na distalização dos primeiros e segundos molares, Bondemark et al. ${ }^{2}$, estudaram dezoito pacientes com má oclusão de Classe II, sobremordida moderada e falta de espaço no arco superior. O estudo foi realizado usando magnetos de um lado e molas de níquel Titânio no lado contrário. A força utilizada nas duas técnicas foi $225 \mathrm{~g}$ e as reativações realizadas a cada quatro semanas. O movimento de distalização foi avaliado através de telerradiografias iniciais, após 6 meses de tratamento. A média obtida na distalização dos molares foi $3.2 \mathrm{~mm}$ para as molas e $2.2 \mathrm{~mm}$ para os Magnetos, com a redução do overbite $3.6 \mathrm{~mm}$. Os resultados indicaram que as molas superelásticas foram mais efetivas do que os magnetos que se mostraram mais desconfortáveis durante o movimento de distalização dos molares.

Carano e Testa ${ }^{4}$, objetivando obter distalização dos molares com um mínimo de inclinação, desenvolveram o Distal Jet constituído por tubos bilaterais ligados a um botão de acrílico, com uma trava móvel para regular a compressão da mola de Níquel Titânio. O desenho do aparelho objetiva

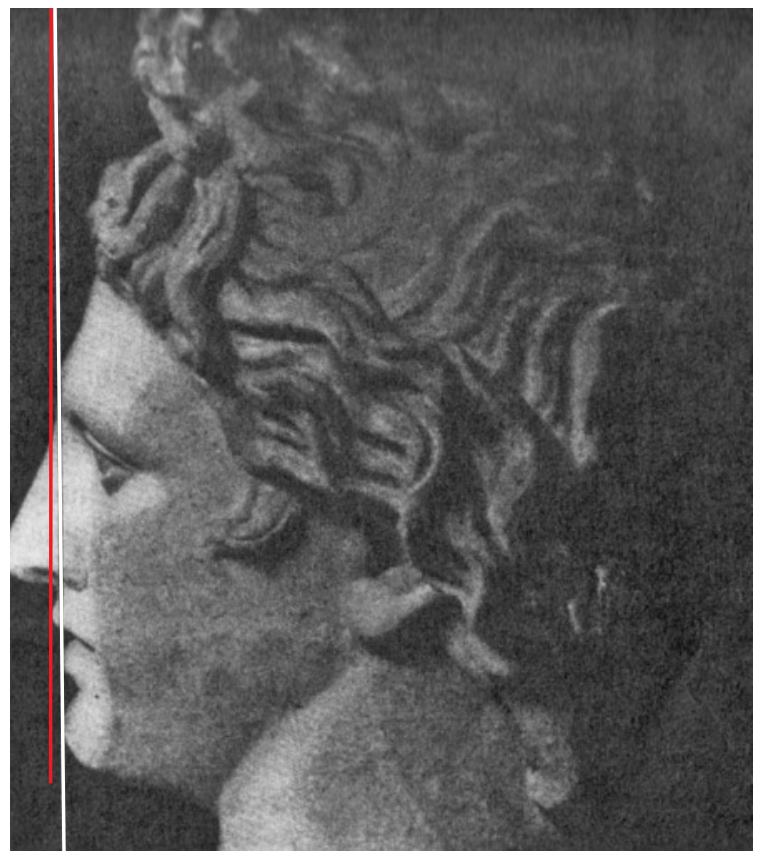

FIGURA 1 - Perfil Grego clássico ${ }^{17}$. 
que a força passe próxima ao centro de resistência do dente promovendo um movimento de translação. As ativações foram realizadas mensalmente.

Objetivando obter melhores resultados na correção da Classe II, Snodgrass ${ }^{18}$ acrescentou uma modificação no Pendex, que seria um apoio soldado ao primeiro molar permanente, unindo-o ao corpo do aparelho. Desta forma, o aparelho teria efeito de um disjuntor tipo Haas modificado. $\mathrm{O}$ aparelho poderia ser usado na dentadura mista e permanente de forma que, somente após a disjunção palatina, o apoio soldado aos molares seria retirado e as molas de TMA seriam ativadas iniciando o processo de distalização dos molares.

Ghosh e Nanda ${ }^{8}$ avaliaram os efeitos do aparelho pêndulo na distalização dos molares superiores e na correção da Classe II. Os autores relataram que o aparelho pêndulo foi eficiente na distalização dos molares com grandes vantagens, visto que necessitavam de mínima cooperação do paciente, além de ser de fácil confecção e baixo custo. A média de distalização dos primeiros molares foi $3,37 \mathrm{~mm}$ e, para os segundos molares, de $2,27 \mathrm{~mm}$. A erupção dos segundos molares exerceu efeito mínimo na distalização dos primeiros molares.

Comparando a efetividade das molas de Níquel Titânio e magnetos, Erverdi et al. ${ }^{6}$, estudaram 15 casos com relação molar Classe II. Magnetos foram aplicados nos primeiros molares direitos e as molas de Níquel Titânio nos molares esquerdo, por um período de 3 meses. Foram utilizadas telerradiografias e modelos antes e após os procedimentos de distalizações. Os resultados mostraram uma maior quantidade de distalização dos molares com as molas de níquel titânio. Ambos procedimentos foram clinicamente aceitáveis; no entanto, os magnetos apresentaram maior custo e desvantagens estéticas.

Observando uma grande quantidade de inclinação dos primeiros molares superiores após o movimento de distalização com o aparelho Pendulum, Byloff et al. ${ }^{3}$, fizeram um novo estudo em que o objetivo principal foi avaliar as mudanças ocorridas nos primeiros molares superiores com a introdução de uma dobra de verticalização. Os resultados mostraram que a introdução da dobra verticalizadora foi eficaz; entretanto, houve uma maior perda de ancoragem, o que se tornaria uma vantagem se uma Classe III estivesse presente. Além disso, a quantidade de movimento distal do primeiro molar ou perda de ancoragem de prémolares e incisivos não sofreram influência pela posição dos segundos molares.

Almeida et al. ${ }^{1}$, objetivando facilitar os procedimentos de reativações, apresentaram uma modificação do aparelho pêndulo/pendex com a incorporação de molas de distalização removíveis introduzidas em tubos telescópio, com intenção de facilitar a realização dos procedimentos de ativação e reativação na cavidade bucal, visto que são manobras de difícil execução, passíveis de provocar lesões na mucosa do palato pelo acesso reduzido.

\section{DESCRIÇÃO DAS CARACTERISTÍCAS, CONFECÇÃO E INSTALAÇÃO DO APARELHO}

O pendulum é um dispositivo intrabucal idealizado com o objetivo de distalizar molares superiores uni ou bilateralmente, com um mínimo de cooperação do paciente e sem desconforto. É constituído de três estruturas principais: apoio palatino de acrílico semelhante a um botão de Nance que funciona como ancoragem, duas molas de TMA 0,32 (podem ser confeccionadas ou pré-fabricadas, ambos da Ormco) (Fig. 2) e grampos de

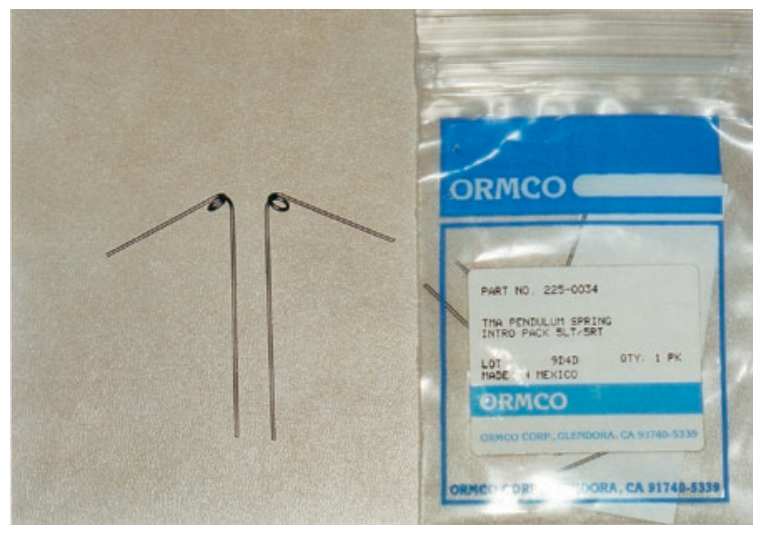

FIGURA 2 - Molas 0,32 de TMA pré-fabricadas da ORMC0. 


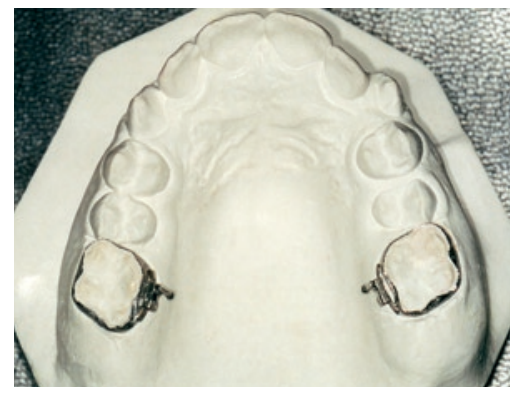

FIGURA 3 - Bandas após transferência da impressão com os tubos linguais.

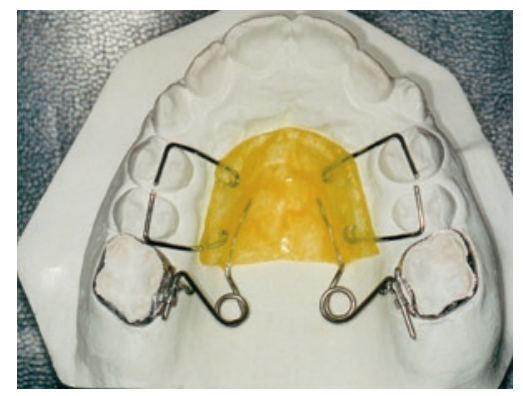

FIGURA 6 - Aparelho após acrilização e polimento.

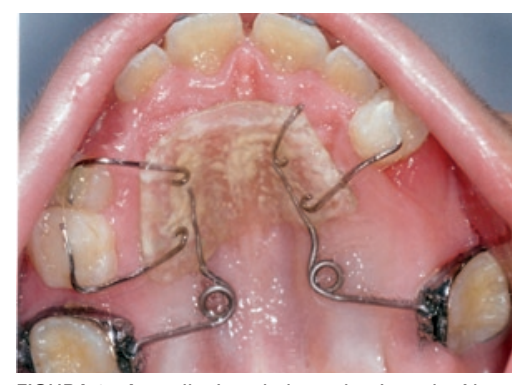

FIGURA 9 - Aparelho instalado na dentição decídua.

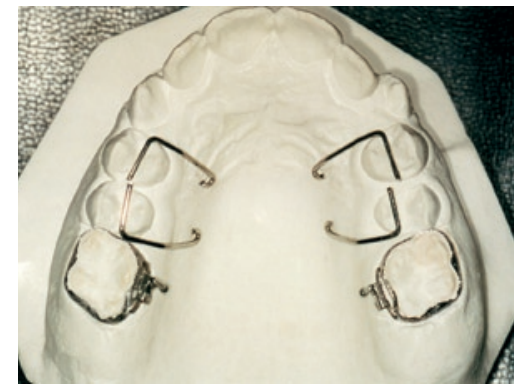

FIGURA 4 - Grampos de apoio com fio de aço 0,36.

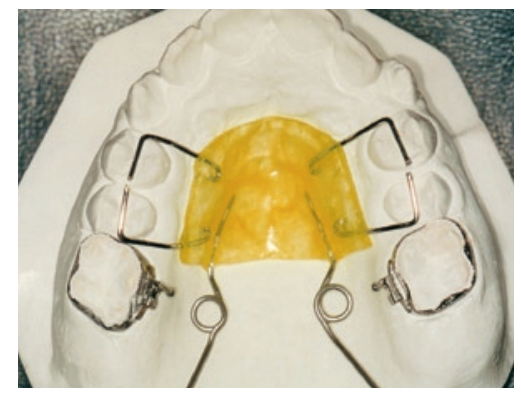

FIGURA 7 - Molas previamente ativadas.

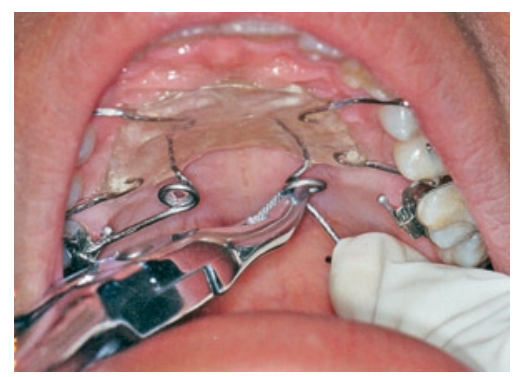

FIGURA 10 - Reativação das molas de TMA.

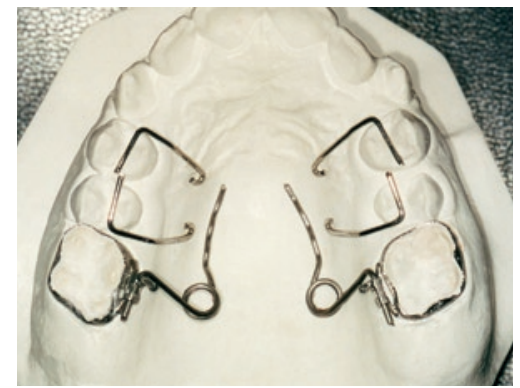

FIGURA 5 - Molas e grampos posicionados para acrilização.

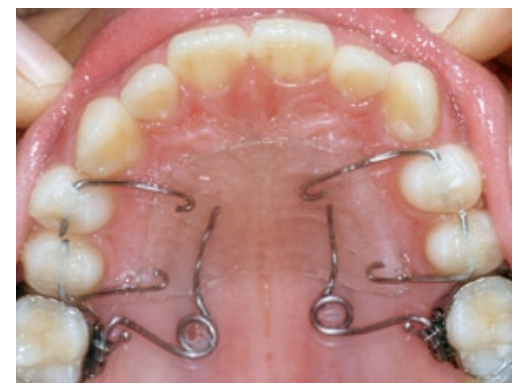

FIGURA 8 - Aparelho instalado na dentição permanente.

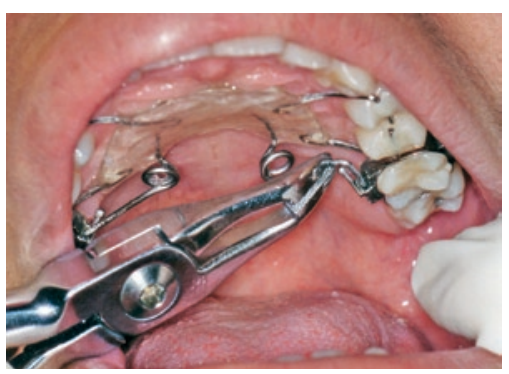

FIGURA 11 - Após ativação e reinserção das molas. apoio confeccionados com fio de aço 0,36 .

A confecção e instalação do aparelho são simples e seguem a sequiência:

- Adaptação das bandas aos primeiros molares, solda dos tubos linguais, moldagem e transferência cuidadosa dos anéis para a impressão (Fig. 3).

- Confecção dos grampos de apoio que devem ser bem adaptados nas oclusais dos primeiros e segundos pré-molares(Fig. 4).

- Confecção e adaptação das molas de TMA aos tubos linguais e ao rebordo alveolar do palato, observando a simetria das molas. (Fig. 5).
- Fixação com cera dos grampos e molas, para posterior acrilização do botão de apoio (Fig. 6). Os helicóides devem ser protegidos com cera evitando a impregnação de resina acrílica.

- Instalação: cimentação dos anéis, seguida pelos procedimentos convencionais de colagem. Os grampos de retenção são fixados com resina nas oclusais dos primeiros e segundos pré-molares ou molares decíduos (Fig. 8, 9).

Basicamente, o mecanismo de ação deste aparelho ocorre pela ativação das molas de TMA que são estendidas paralelas à rafe palatina antes da 
instalação do mesmo (Fig. 7). Instalado o aparelho, insere-se as molas de TMA com auxílio de um alicate Weingart (Fig. 11).

As ativações são realizadas a cada três ou quatro semanas, para que a força dissipada pelas molas seja avaliada. Para reativação, a mola é presa com alicate Weingart e a extremidade estendida em direção à linha média (Fig. 10).

\section{INDICAÇÕES}

O aparelho distalilizador pêndulo, quando adequadamente planejado, torna-se um excelente aliado não só na correção da Classe II mas, também nos casos limítrofes entre extração e não extração, visto que o mesmo independe da colaboração do paciente e apresenta resultados satisfatórios em grande parte dos casos indicados. No entanto, alguns fatores devem ser considerados como a tendência de abertura da mordida anterior. Esta tendência em pacientes braquicefálico e mesocefálico é corrigida espontaneamente, porém, torna-se um problema em pacientes dolicocefálicos; outro inconveniente é a dificuldade de higienização.

O movimento de distalização após a erupção dos segundos molares não representa uma contraindicação, embora possa apresentar alguma dificuldade no que diz respeito ao controle da inclinação vestibular dos incisivos superiores, enquanto para a má oclusão de Classe III esta perda de ancoragem torna-se positivo.

A correção de Classe II unilateral é bem indicada nos casos onde ocorreu a perda precoce dos segundos molares decíduos e conseqüente mesialização dos molares permanentes. Correção na inclinação mesial dos primeiros molares permanentes sob segundos molares decíduos anquilosados.

\section{PERDA DE ANCORAGEM E ESTABILIZAÇÃO DOS MOLARES APÓS DISTALIZAÇÃO}

A opção de tratamento intra-bucal para correção da má oclusão de Classe II tem sido adotada pelos ortodontistas, visto que, embora exista algum inconveniente, estes procedimentos, por serem fixos, dispensam a cooperação do paciente, que em alguns tratamentos torna-se um problema no relacionamento pais/profissional/paciente ${ }^{15}$.

A perda de ancoragem e a estabilização dos molares após as distalizações deverão ser cuidadosamente monitoradas evitando insucessos no processo de distalização.

Segundo Gianelly et al. ${ }^{7}$, a perda de ancoragem está diretamente relacionada com a erupção dos segundos molares; deste modo, na ausência destes, foi observada uma distalização de $80 \%$ e uma perda de ancoragem de $20 \%$. No entanto, quando os segundos molares tinham irrompido, estes índices passaram para 65\% de distalização e 35\% da perda de ancoragem. De acordo com os autores, o tempo de tratamento aumenta na presença dos segundos molares.

Jones e White ${ }^{11}$ observaram que os pacientes que utilizaram aparelho fixo nos dentes superiores apresentaram uma maior inclinação vestibular dos dentes anteriores, durante a fase de nivelamento.

Para minimizar a perda de ancoragem, Locatelli et al. $^{13}$, recomendam o uso de elásticos de Classe II.

Gosh e Nanda ${ }^{8}$ não observaram perda de ancoragem significativa durante a distalização dos primeiros molares, quando os segundos molares superiores já tinham irrompido.

Objetivando melhores resultados na quantidade de distalização dos molares, Martins et al. ${ }^{14}$, promoveram a distalização primeiramente dos segundos molares sendo que, após a estabilização destes, é que os primeiros molares seriam distalizados.

A estabilização dos molares, após distalização, deve fazer parte de um protocolo de tratamento, visto que existe uma tendência acentuada de ocorrer mesialização, principalmente, se os segundos molares já estiverem erupcionado.

Gianelly et al. ${ }^{7}$ indicam uma ancoragem extrabucal, preferencialmente tração e direção superior para verticalização da raiz. Estes autores recomendam ainda uma pausa para iniciar a retração dos pré-molares, devido à instabilidade dos molares 
logo após distalização.

Jones e White ${ }^{11}$ utilizam placa de Hawley para estabilização dos molares após distalização, enquanto Hilgers ${ }^{9}$ recomenda o uso de um arco utilidade, um arco contínuo com ômegas justos e amarrados, além de um aparelho extrabucal e também um botão de Nance ("Insta-Nance") imediatamente após a retirada do aparelho Pêndulo.

Os autores Carano e Testa ${ }^{4}$ relataram o uso do próprio aparelho distal Jet para estabilizar os molares isolando a mola com resina e liberando os pré-molares.

Gosh e Nanda ${ }^{8}$ estabilizam os molares distalizados com botão de Nance fixado nos primeiros molares e com aparelho extrabucal.

Com vasta experiência clínica com distalizador tipo Jones Jig, Suguino et al. ${ }^{19}$, relataram utilizar como ancoragem uma barra palatina, botão de Nance e placa de Hawley modificada com grampos auxi- liares e resina no espaço obtido, procedimentos que poderiam ser utilizados isolados ou combinados.

\section{AVALIAÇÃO DE CASOS CLÍNICOS}

\section{Caso 1 \\ Dados Gerais}

A paciente R.B.O, 12 anos e 7 meses, bom estado geral de saúde, apresentava como queixa principal os caninos vestibularizados (Fig.13).

\section{Análise Facial}

Em norma frontal, a paciente apresentava boa proporção entre os terços faciais, simetria facial e bom selamento labial (Fig. 12).

No sorriso, apresentava comprometimento da estética facial pelos caninos mal posicionados (Fig. 13)

$\mathrm{Na}$ análise lateral, observa-se bom ângulo nasolabial e linha queixo-pescoço satisfatória (Fig. 14).

\section{Caso 1}

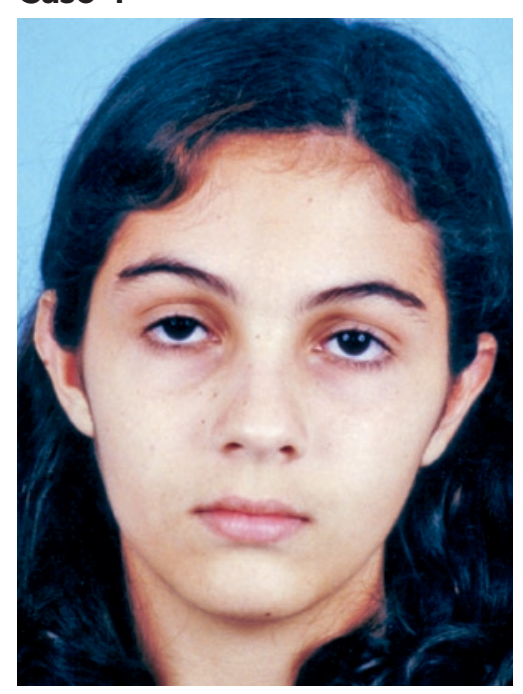

FIGURA 12 - Frontal inicial.

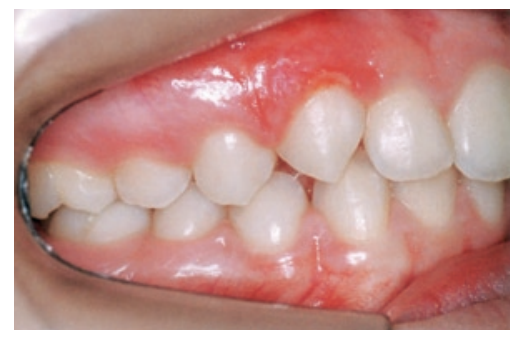

FIGURA 15 - Intrabucal direita.

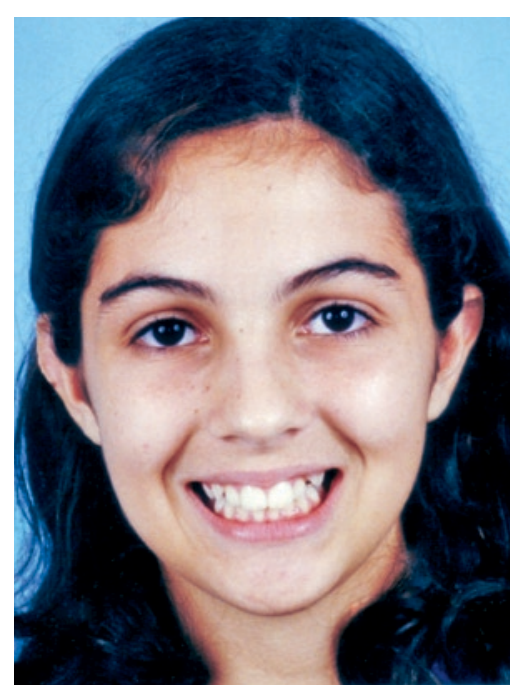

FIGURA 13 - Sorriso inicial.

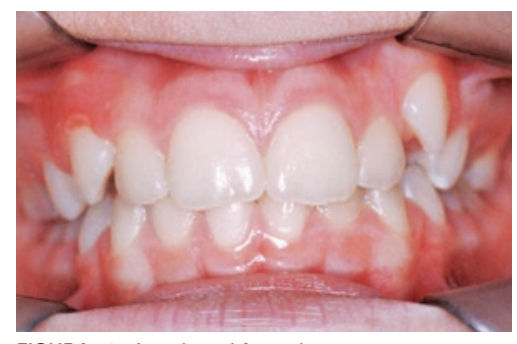

FIGURA 16 - Intrabucal frontal.

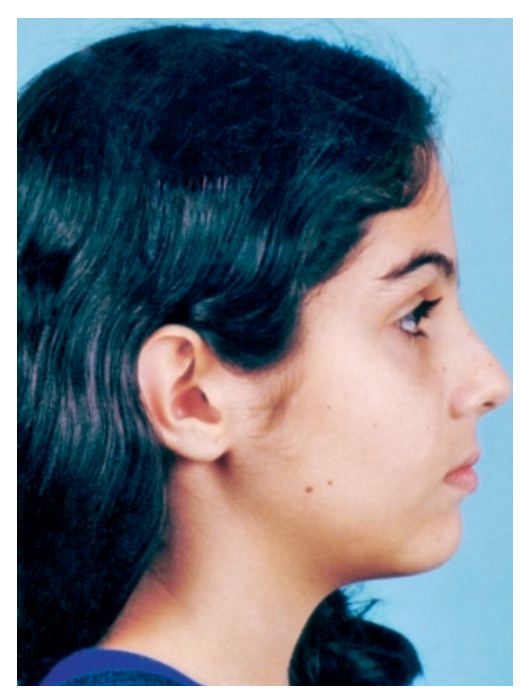

FIGURA 14 - Perfil inicial.

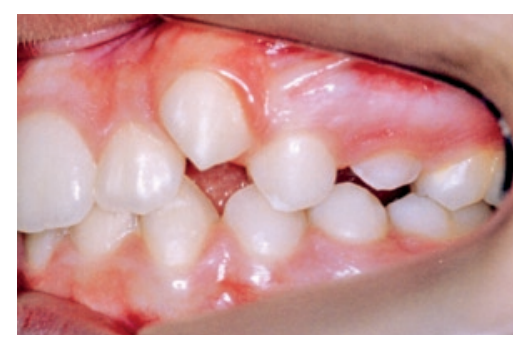

FIGURA 17 - Intrabucal esquerda. 


\section{Exame Clínico}

A paciente apresentava má oclusão de Classe II, a cúspide mesiolingual dos primeiros molares superiores anteriormente ao sulco marginal dos primeiros molares inferiores, relação de caninos e pré-molares de Classe II com desvio da linha média, sobremordida profunda, apinhamento na região anterior superior com falta de espaço para caninos (Fig. 15, 16, 17).

\section{Análise Radiográfica}

$\mathrm{Na}$ análise radiográfica panorâmica, havia ausência de periapicopatias, os segundos molares em erupção e os terceiros molares em rizogênese incompleta (Fig. 18).

\section{Análise de Modelos}

A paciente apresentava discrepância de modelos de $-6 \mathrm{~mm}$ no arco superior, caninos em infra-

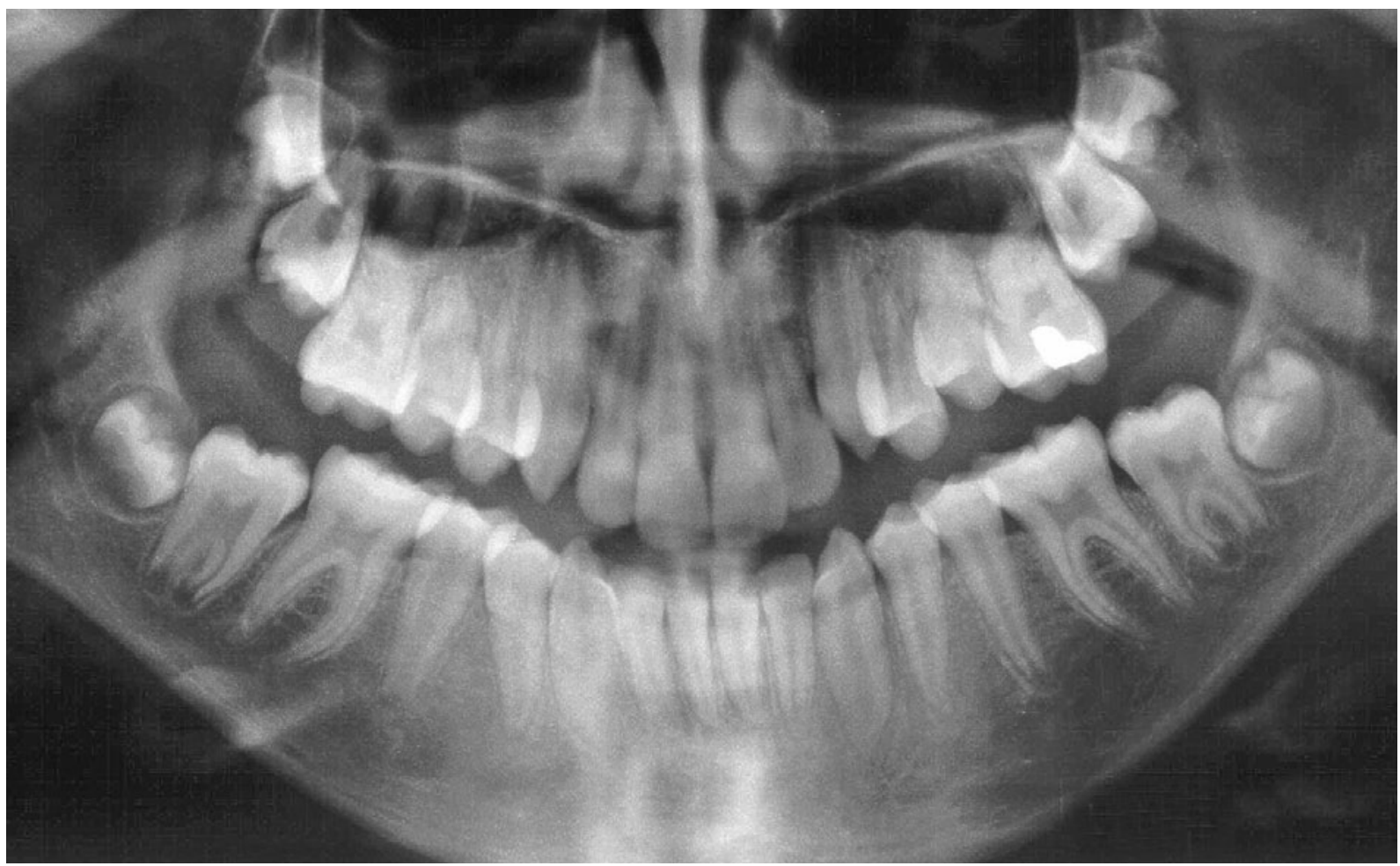

FIGURA 18 - Radiografia panorâmica inicial.

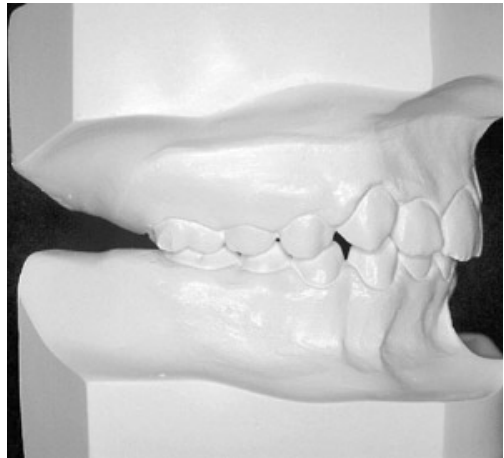

FIGURA 19 - Modelo direito inicial.

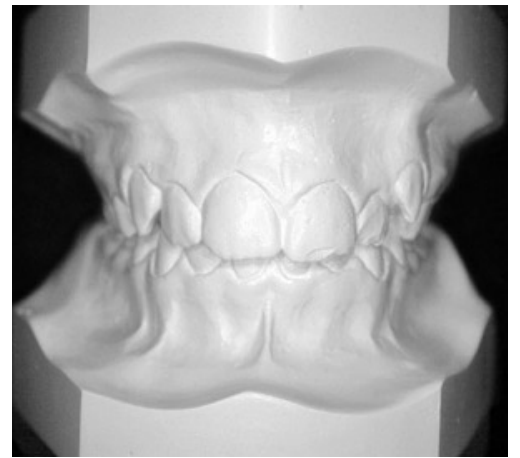

FIGURA 20 - Modelo Frontal inicial.

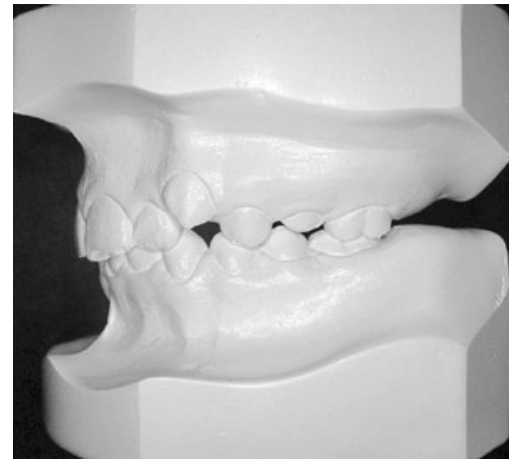

FIGURA 21 - Modelo esquerdo inicial. 
vestíbulo-versão e discreto apinhamento no arco inferior que, quando em oclusão, mostrava desvio da linha média. (Fig. 19, 20, 21).

\section{Diagnóstico}

Má oclusão de Classe II, apinhamento superior na região de caninos em infravestíbulo-versão.

\section{Plano de Tratamento}

Foi planejado distalização dos molares, através do pendulum objetivando uma relação de Classe I, bem como uma melhor relação de prémolares; posteriormente, foi utilizado o arco extrabucal noturno e barra transpalatina como ancoragem (Fig. 22 a 28).

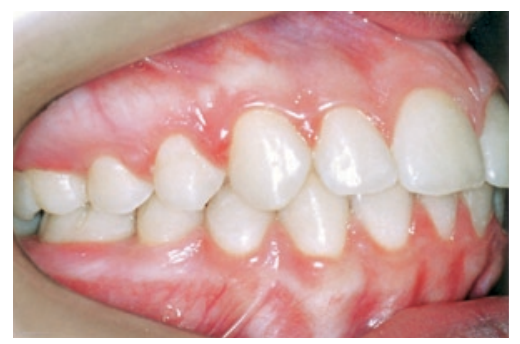

FIGURA 23 - Intrabucal direita final.

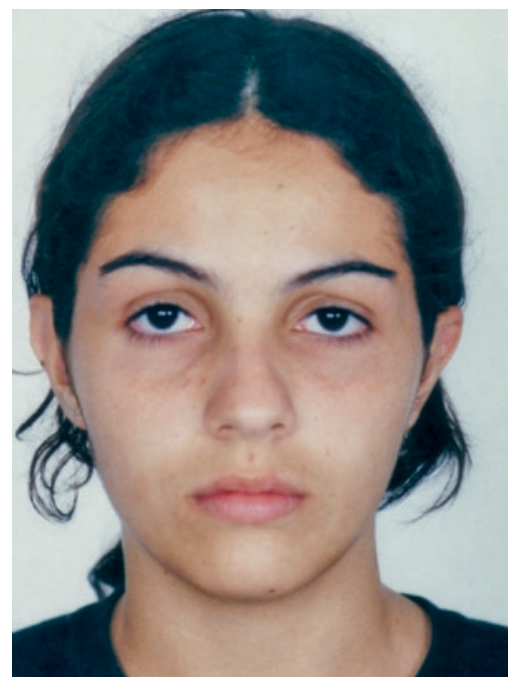

FIGURA 26 - Frontal final.

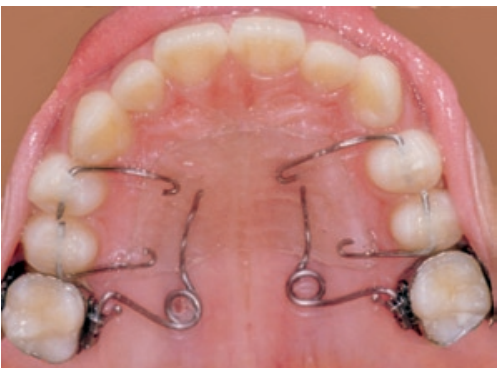

FIGURA 22 - Intrabucal com Pêndulo.

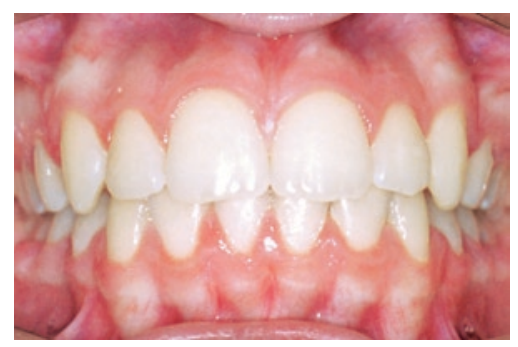

FIGURA 24 - Intrabucal frontal final.

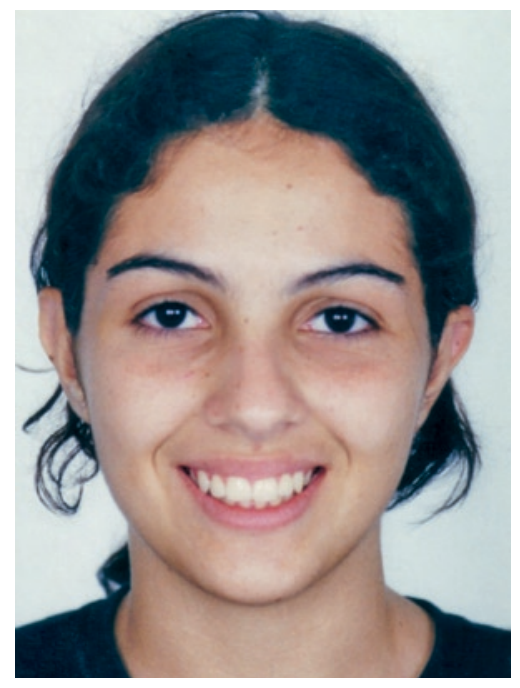

FIGURA 27 - Sorriso final.

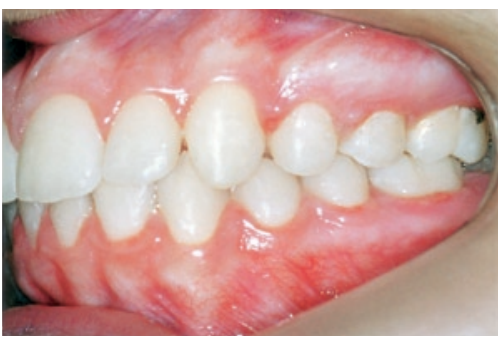

FIGURA 25 - Intrabucal esquerda final.

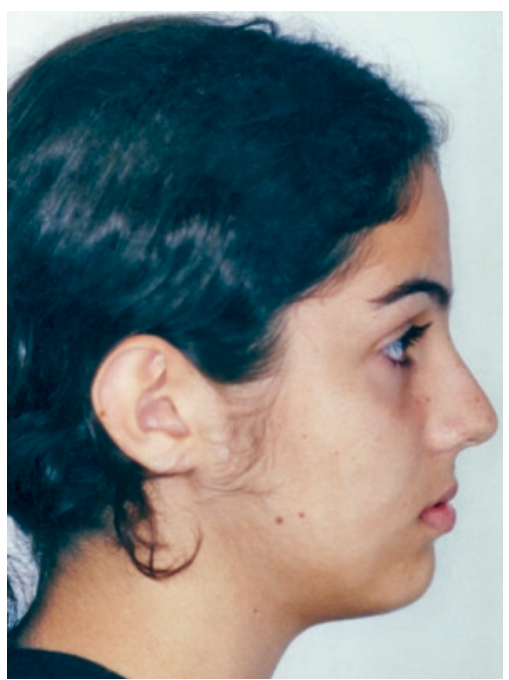

FIGURA 28 - Perfil final. 


\section{Caso 2}

\section{Dados Gerais}

A paciente I.R.O, 11 anos e 5 meses, bom estado geral de saúde, apresentava como queixa principal os caninos vestibularizados (Fig. 30).

\section{Análise Facial}

$\mathrm{Na}$ análise frontal, a paciente apresenta boa proporção entre os terços faciais, simetria facial e bom selamento labial (Fig. 29).

No sorriso, observou-se o comprometimento da estética facial pelos caninos mal posicionados (Fig. 30).
$\mathrm{Na}$ análise lateral, notava-se bom ângulo nasolabial, linha queixo-pescoço satisfatória (Fig. 31).

\section{Exame Clínico}

A paciente apresentava uma má oclusão de Classe II, com desvio da linha média, apinhamento na região anterior superior com falta de espaço para caninos (Fig. 32, 33, 34).

\section{Análise Radiográfica}

$\mathrm{Na}$ análise radiográfica panorâmica, havia aspecto de normalidade, segundos molares em erupção e os terceiros molares em rizogênese incompleta (Fig. 35).

\section{Caso 2}

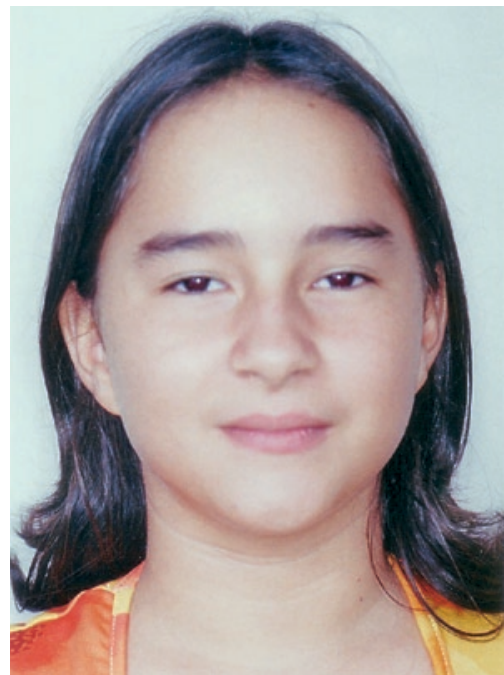

FIGURA 29 - Frontal inicial.

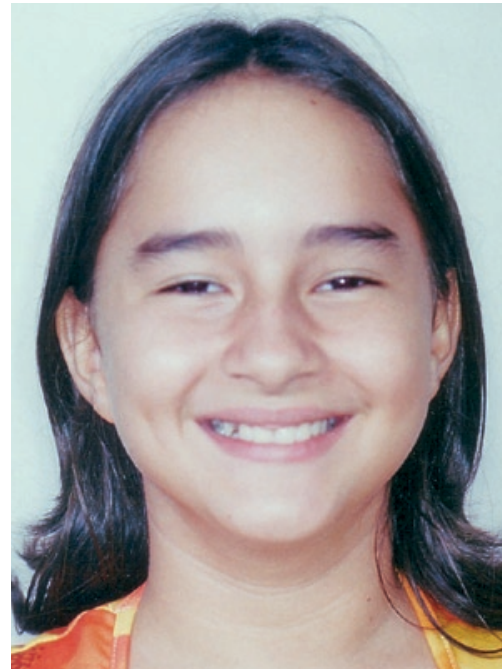

FIGURA 30 - Sorriso inicial.

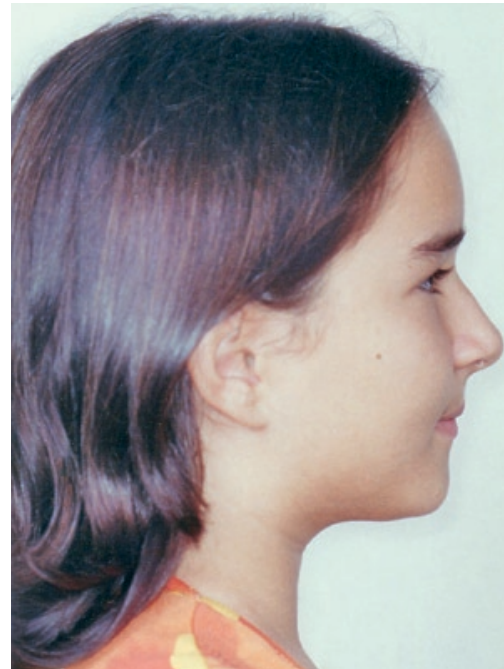

FIGURA 31 - Perfil inicial.

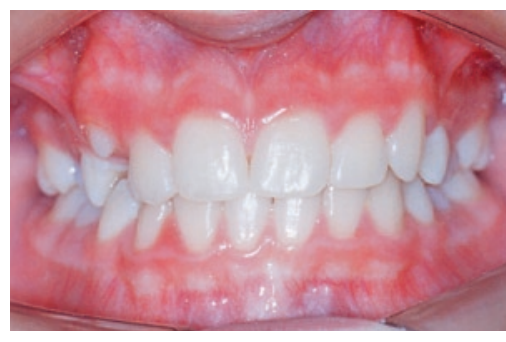

FIGURA 33 - Intrabucal esquerda inicial.

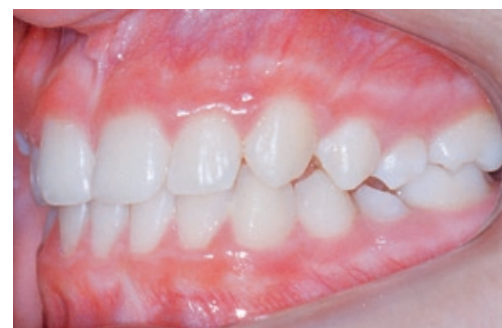

FIGURA 34 - Intrabucal frontal inicial. 


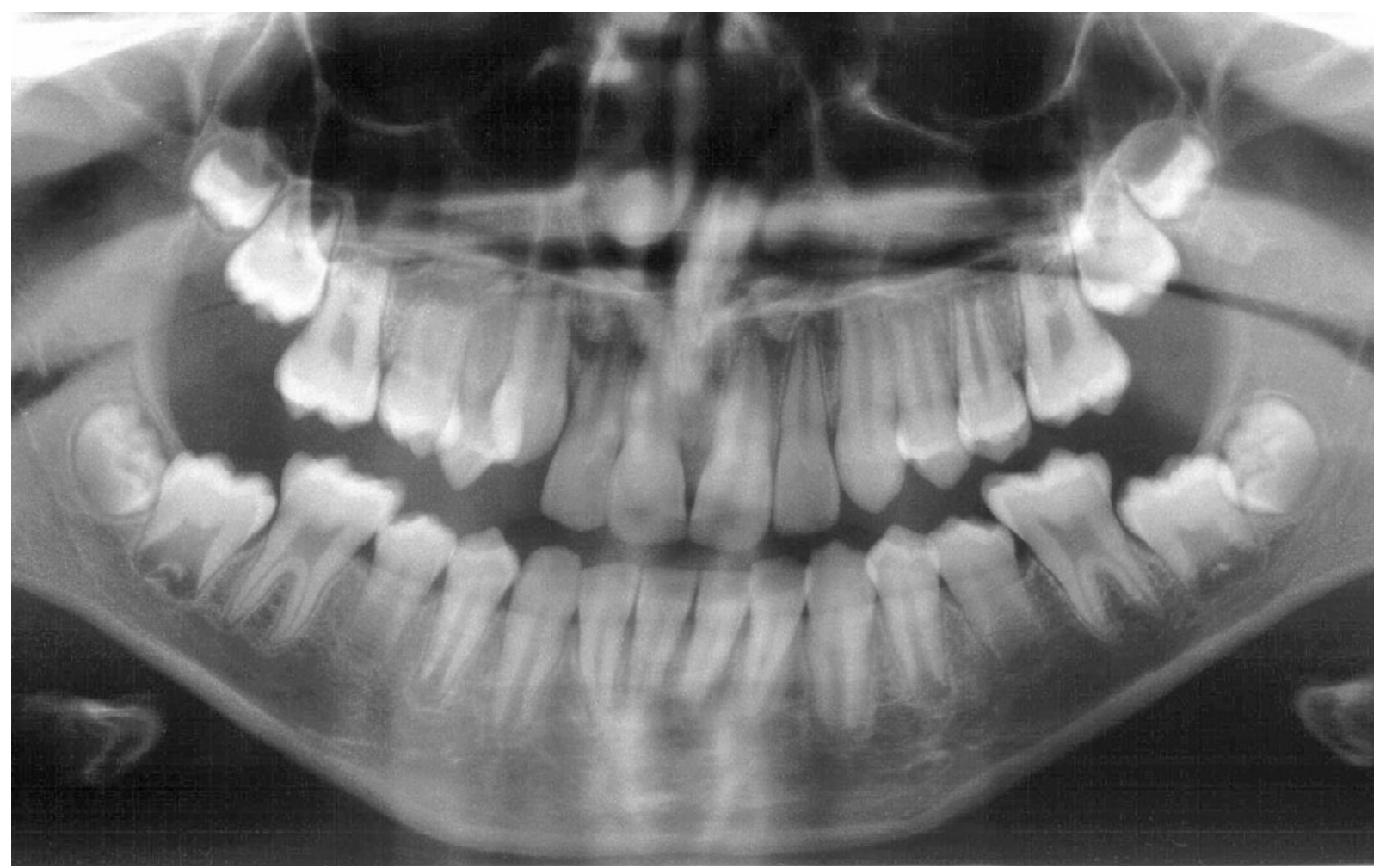

FIGURA 35 - Radiografia panorâmica inicial.

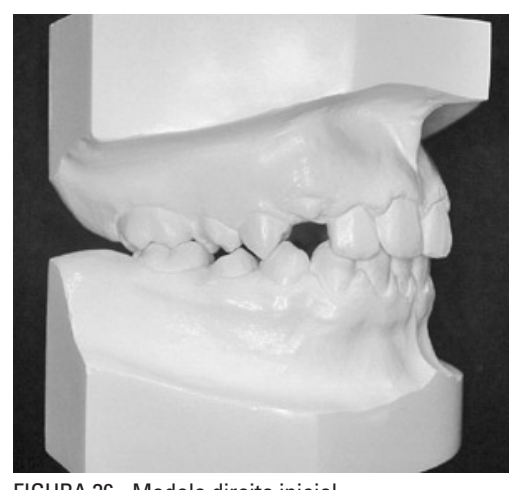

FIGURA 36 - Modelo direito inicial.

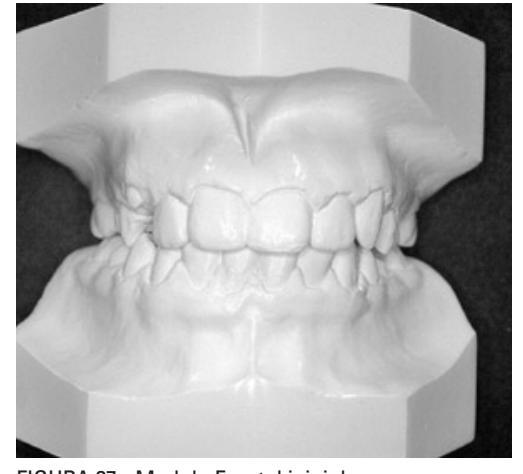

FIGURA 37 - Modelo Frontal inicial.

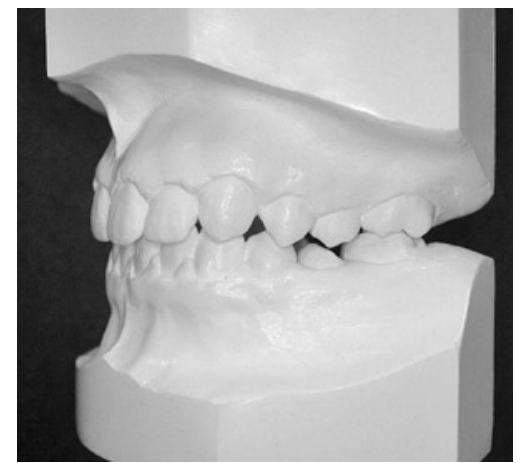

FIGURA 38 - Modelo esquerdo inicial.

\section{Análise de Modelos}

A paciente apresentava discrepância de modelos de $-6 m m$ no arco superior, caninos em infravestíbulo-versão e discreto apinhamento no arco inferior que quando em oclusão mostrava desvio da linha média. (Fig. 36, 37, 38).

\section{Diagnóstico}

Má oclusão de Classe II, apinhamento superior na região de caninos que se encontram em infravestíbulo-versão.

\section{Plano de Tratamento}

Foi planejado distalização dos molares, através do pendulum objetivando uma relação de Classe I, bem como uma melhor relação de pré-molares, posteriormente foi utilizado o arco extrabucal noturno como ancoragem (Fig. 39 a 45). 


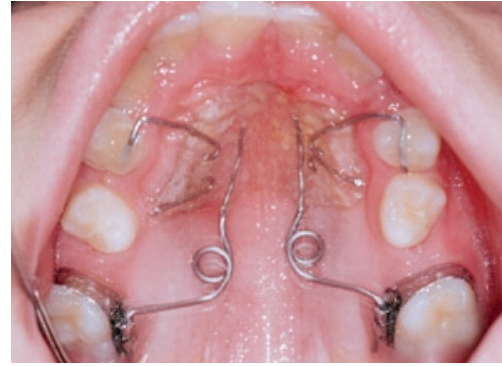

FIGURA 39 - Intrabucal com Pendulum.

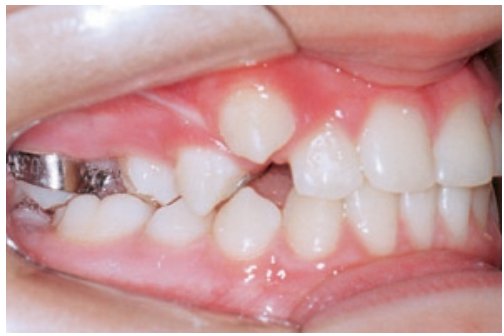

FIGURA 40 - Intrabucal direita após a distalização dos molares.

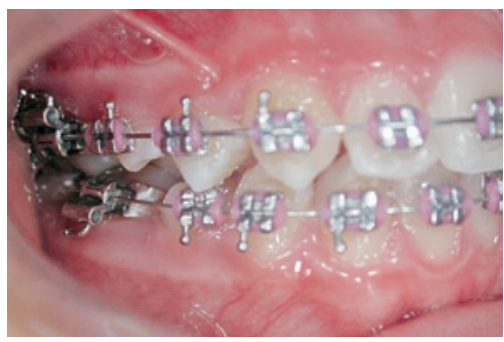

FIGURA 43 - Intrabucal direita no nivelamento.

\section{Caso 3}

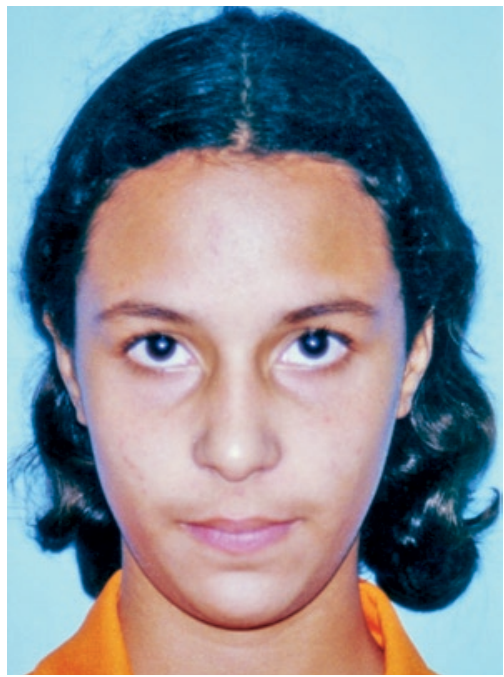

FIGURA 46 - Frontal inicial.

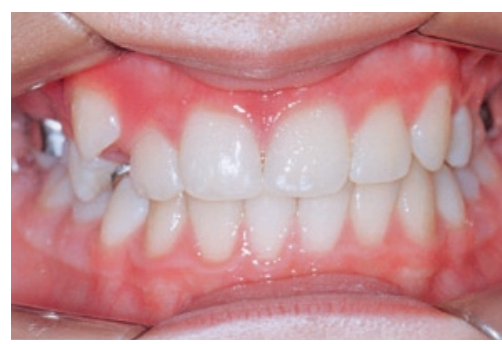

FIGURA 41 - Intrabucal frontal após a distalização dos molares.

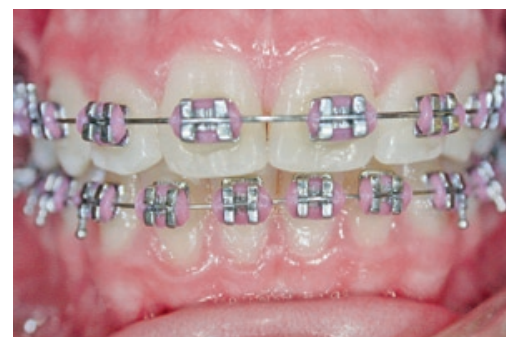

FIGURA 44 - Intrabucal frontal no nivelamento.

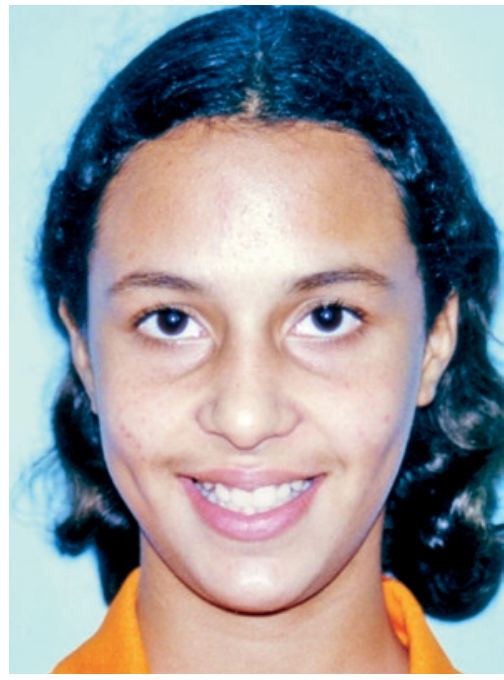

FIGURA 47 - Sorriso inicial.

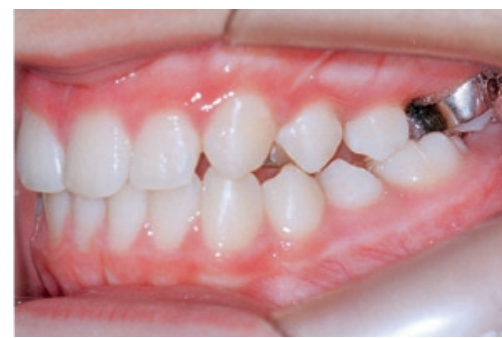

FIGURA 42 - Intrabucal esquerda após a distalização dos molares

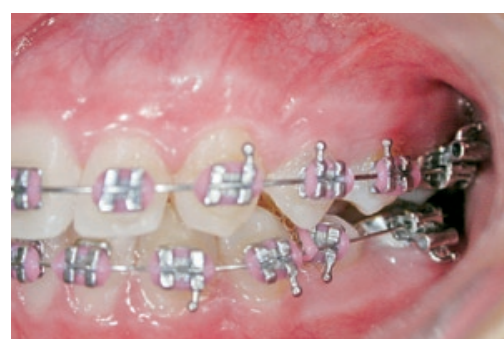

FIGURA 45 - Intrabucal esquerda no nivelamento.

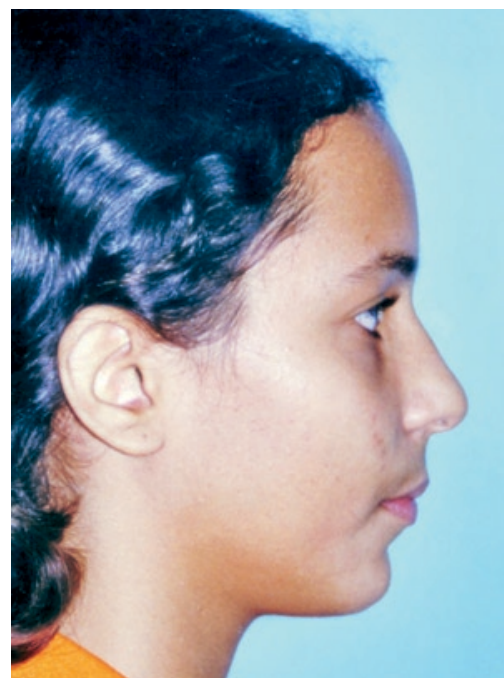

FIGURA 48 - Perfil inicial. 


\section{Caso 3}

\section{Dados Gerais}

A paciente K.P.T., 14 anos e 2 meses, bom estado geral de saúde, apresentava como queixa principal os caninos vestibularizados (Fig. 47).

\section{Análise Facial}

Em norma frontal a paciente apresentava boa proporção entre os terços faciais, simetria facial e bom selamento labial (Fig. 46).

Em análise lateral, havia um bom ângulo nasolabial, linha queixo-pescoço satisfatória (Fig. 48).
Caninos vestibularizados comprometendo a estética facial no sorriso (Fig. 47).

\section{Exame Clínico}

Apinhamento anterior, caninos vestibularizados, sobremordida profunda, relação molares e caninos de Classe II.

\section{Análise Radiográfica}

Ausência de periapicopatias, segundos molares irrompidos e os terceiros molares com rizogênese incompleta;

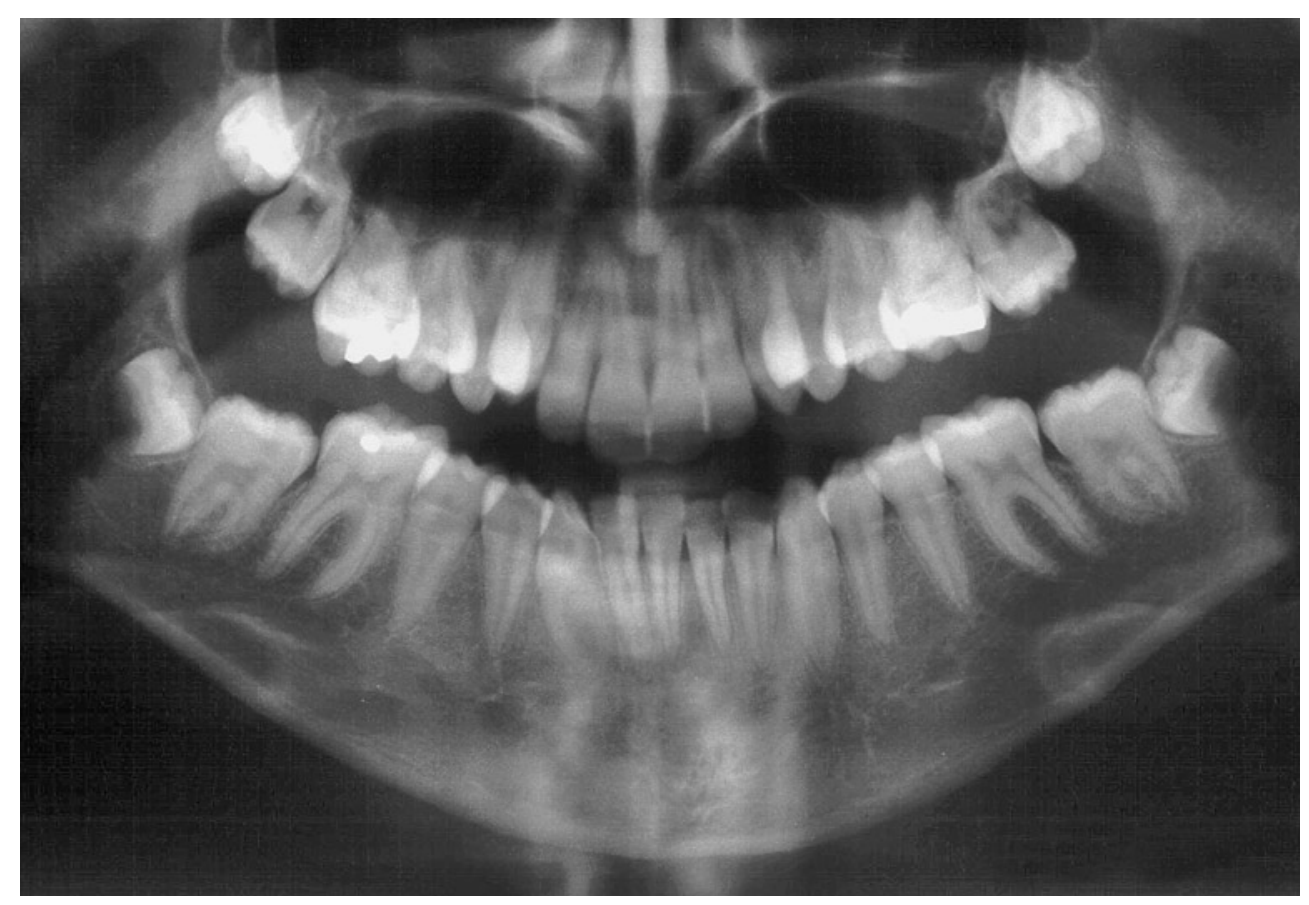

FIGURA 49 - Radiografia panorâmica inicial.

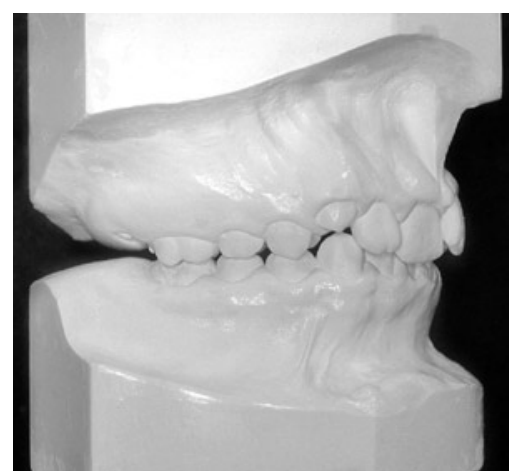

FIGURA 50 - Modelo direito inicial

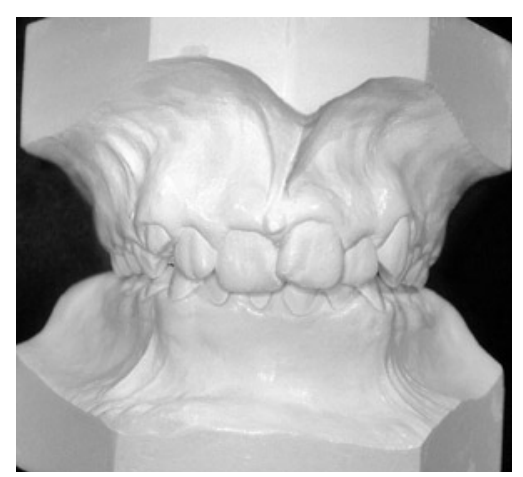

FIGURA 51 - Modelo esquerdo inicial.

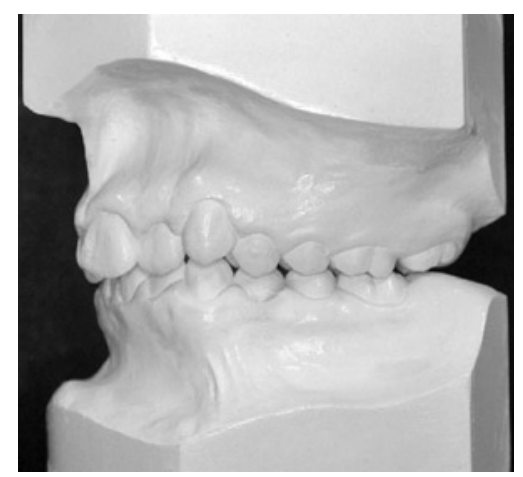

FIGURA 52 - Modelo Frontal inicial. 


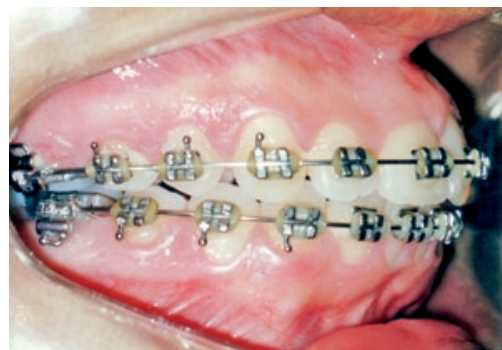

FIGURA 53 - Intrabucal direita na finalização.

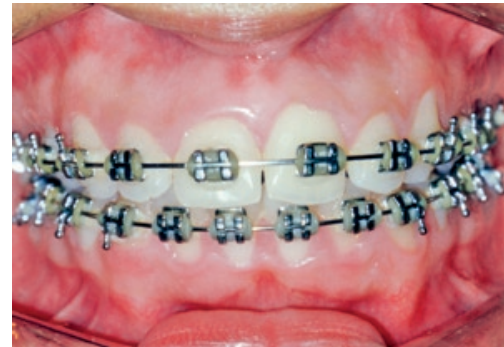

FIGURA 54 - Intrabucal frontal na finalização.

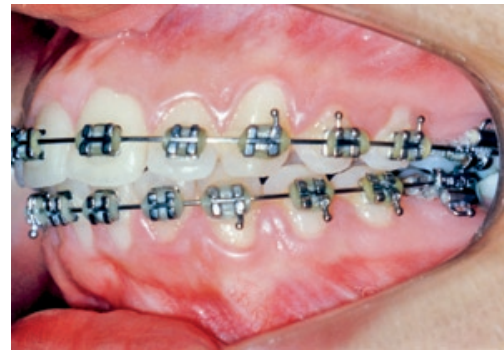

FIGURA 55 - Intrabucal esquerda na finalização.

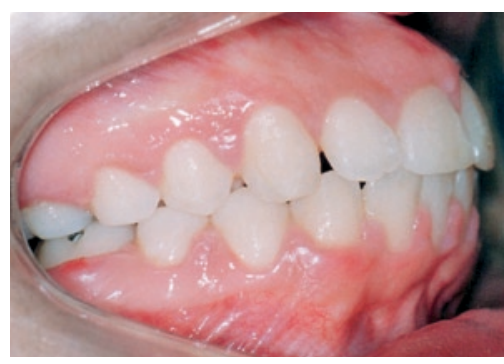

FIGURA 56 - Intrabucal direita final.

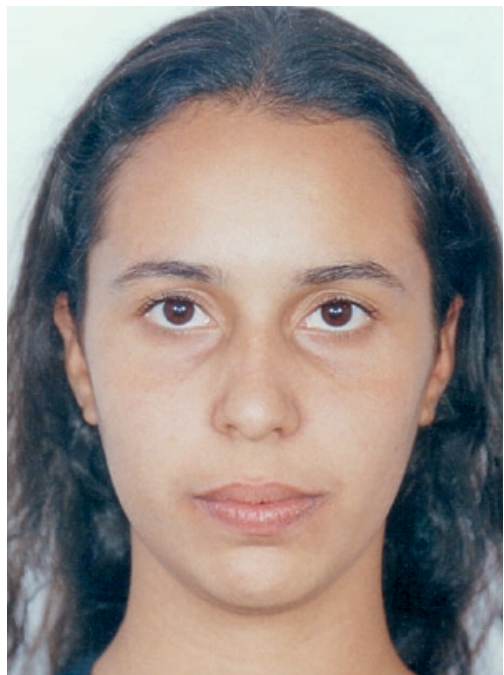

FIGURA 59 - Frontal final.

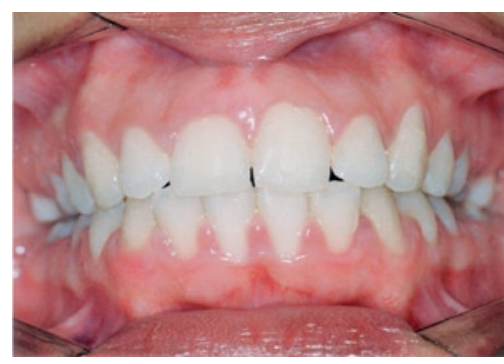

FIGURA 57 - Intrabucal frontal final.

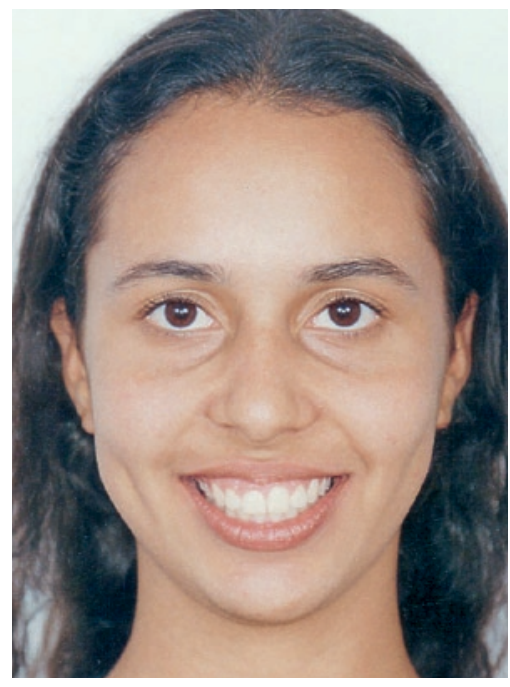

FIGURA 60 - Sorriso final.

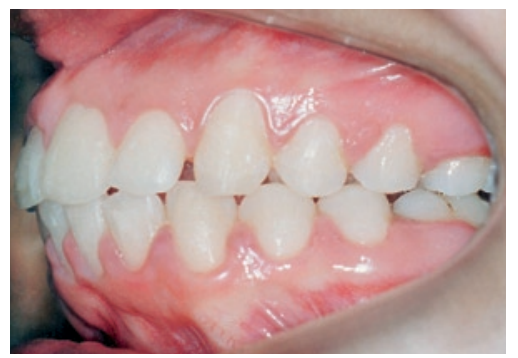

FIGURA 58 - Intrabucal esquerda final.

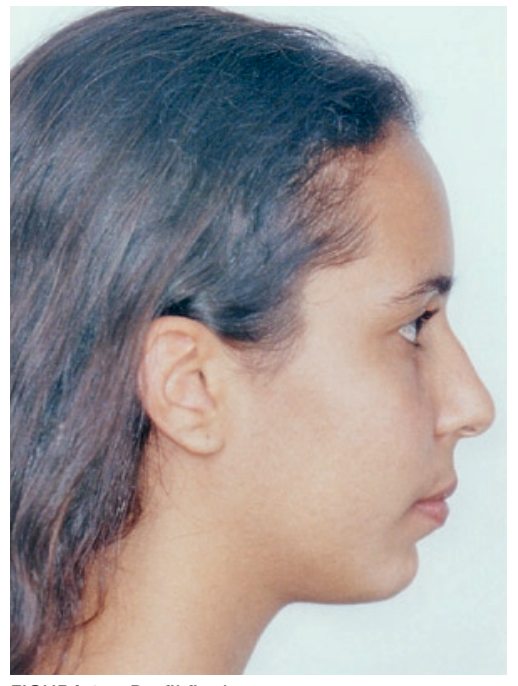

FIGURA 61 - Perfil final.

\section{Análise de Modelos}

A paciente apresentava discrepância de modelos $-7 \mathrm{~mm}$ no arco superior e $-3 \mathrm{~mm}$ inferior (Fig. $50,51,52)$.

\section{Diagnóstico}

Má oclusão de Classe II, apinhamento superior na região de caninos.

\section{Plano de Tratamento}

Foi planejado distalização de molares, através do pendulum objetivando uma relação Classe I, e segunda fase com aparelho fixo total e elástico Classe II (Fig. 53 a 61). 


\section{Caso 4}

\section{Dados Gerais}

O paciente P. F. B , 12 anos, bom estado geral de saúde, queixa principal caninos vestibularizados e apinhamento anterior.

\section{Análise Facial}

O paciente apresentava boa proporção entre os terços faciais, selamento labial, sorriso esteticamente prejudicado pelos caninos vestibularizados, linha queixo-pescoço curta (característica familiar) (Fig. 62, 63, 64).

\section{Exame Clínico}

O paciente apresentava uma má oclusão de Classe II, apinhamento anterior com caninos vestibularizados. Tendência à mordida aberta devido à interposição lingual, o que foi controlado durante o processo de distalização (Fig. 65, 66, 67).

\section{Análise Radiográfica}

Segundos molares irrompidos e terceiros molares com rizogênese incompleta (Fig. 68).

\section{Análise Modelos}

Discrepância de $-8 \mathrm{~mm}$ no arco superior, arco

\section{Caso 4}

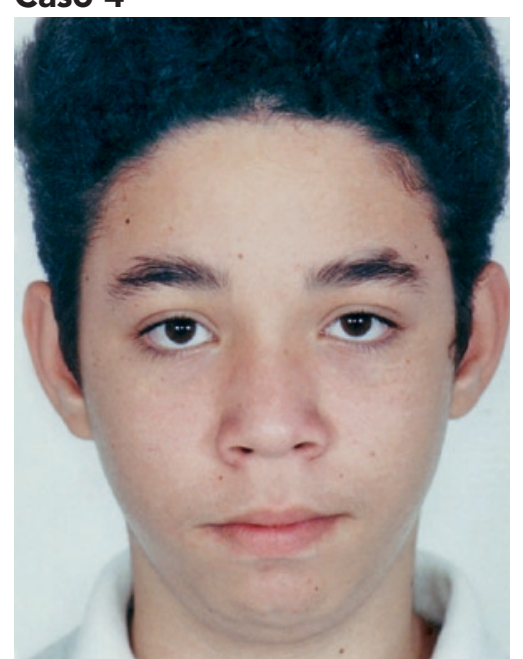

FIGURA 62 - Frontal inicial.

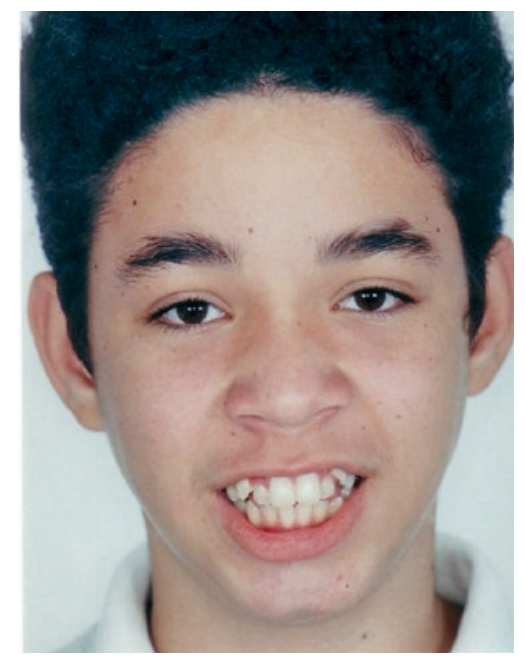

FIGURA 63 - Sorriso inicial.

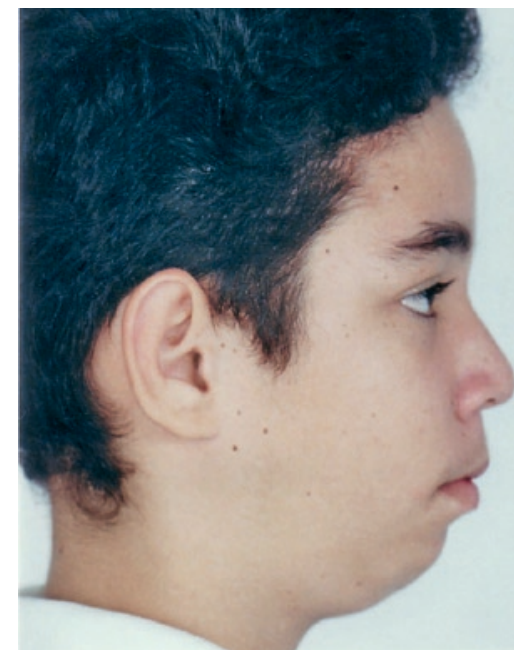

FIGURA 64 - Perfil inicial.

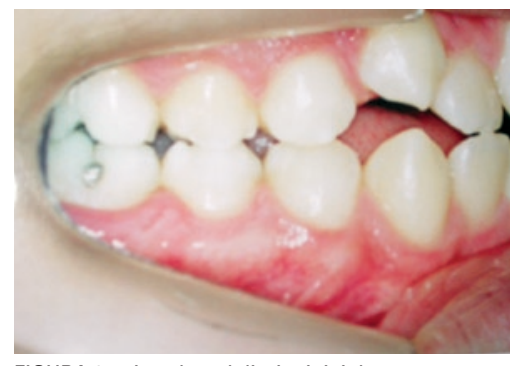

FIGURA 65 - Intrabucal direita inicial.

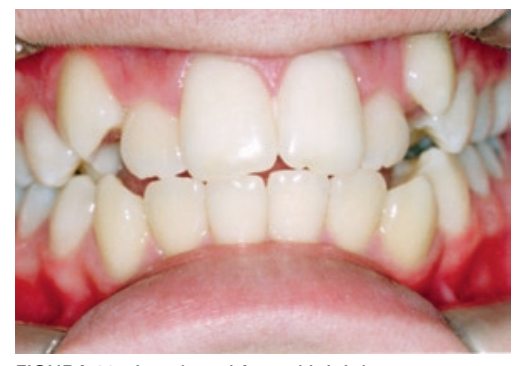

FIGURA 66 - Intrabucal frontal inicial.

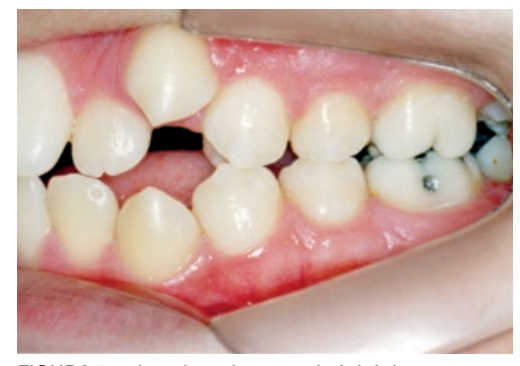

FIGURA 67 - Intrabucal esquerda inicial. 
inferior praticamente alinhado, ausência de overjet. (Fig. 69, 70, 71).

\section{Diagnóstico}

Má oclusão de Classe II, apinhamento na região anterior-superior.

\section{Plano de Tratamento}

Aparelho de distalização dos molares do tipo
Pendulum objetivando resolver o apinhamento anterior e a relação molar de classe II. Ancoragem com botão de Nance e Extrabucal, tração alta, uso noturno para melhor controle da tendência à mordida aberta e aparelho fixo total (Fig. 72 a 82). Nesta fase, o uso do Extrabucal foi importante para estabilizar e manter a distalização, e normalmente há a colaboração do paciente justificada pelo curto período de uso.

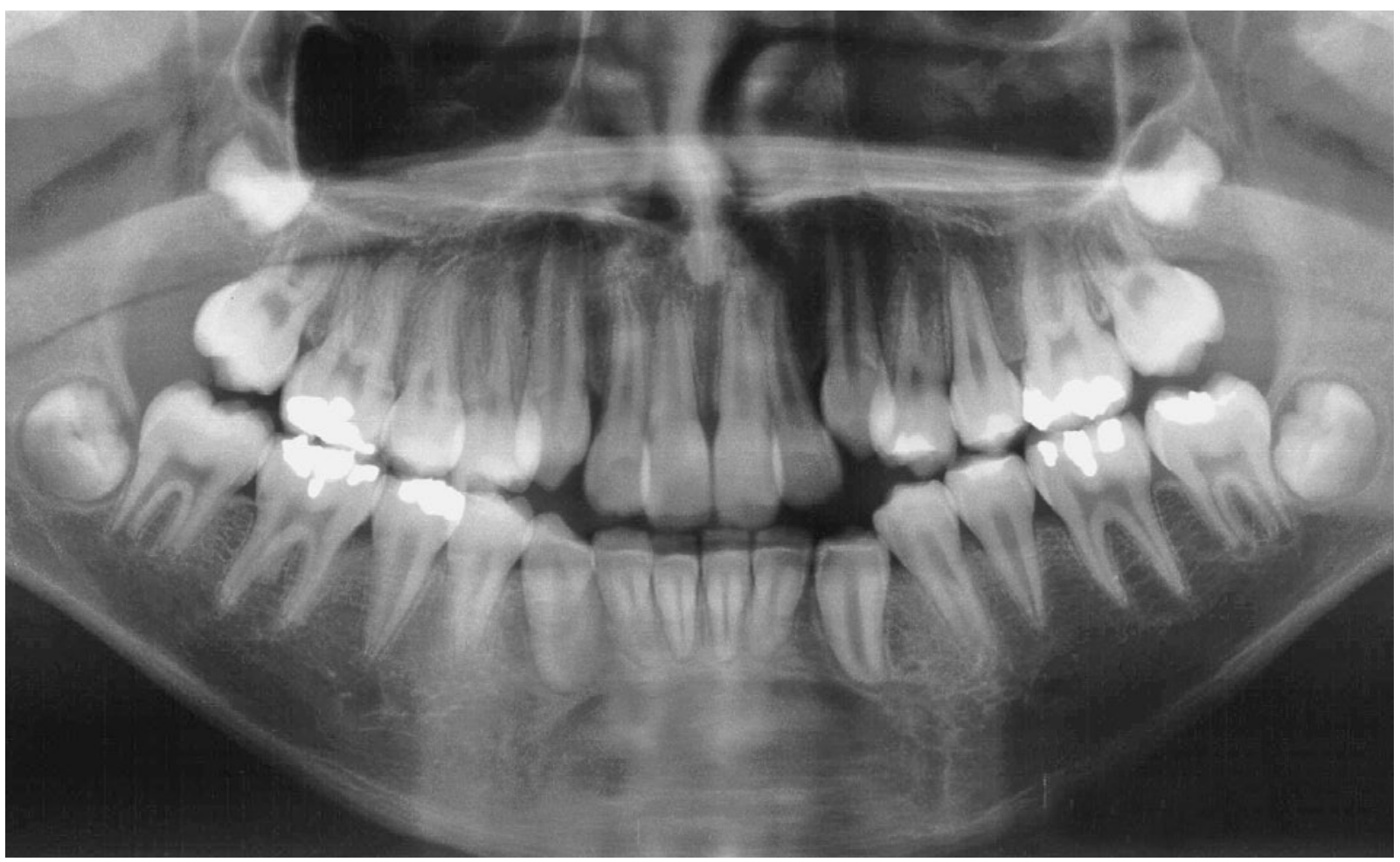

FIGURA 68 - Radiografia panorâmica inicial.

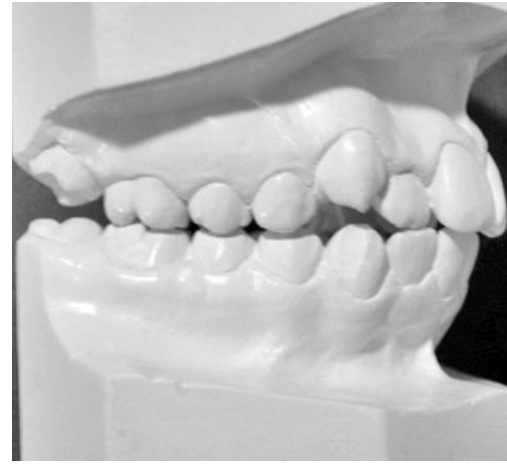

FIGURA 69 - Modelo direito inicial.

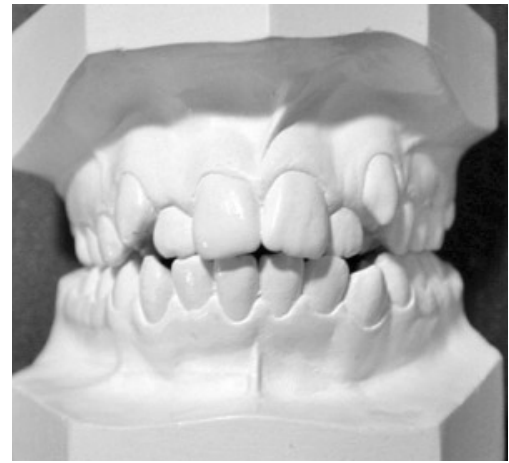

FIGURA 70 - Modelo frontal inicial.

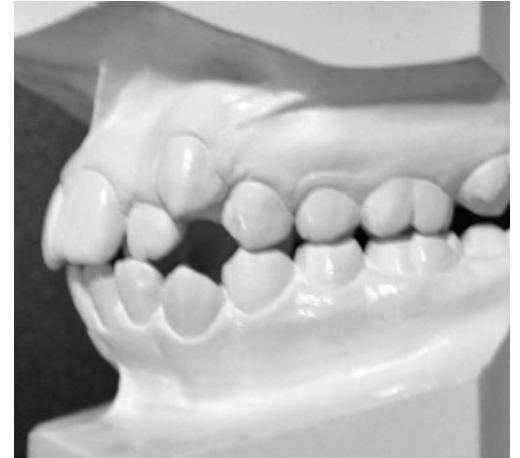

FIGURA 71 - Modelo esquerdo inicial. 


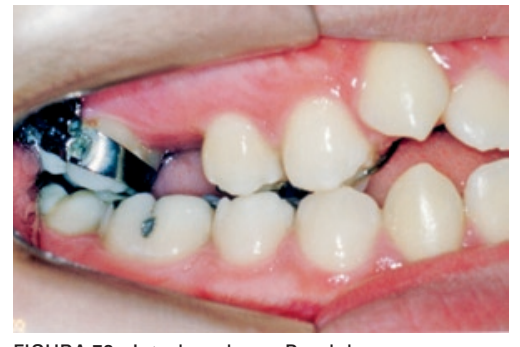

FIGURA 72 - Intrabucal com Pendulum.

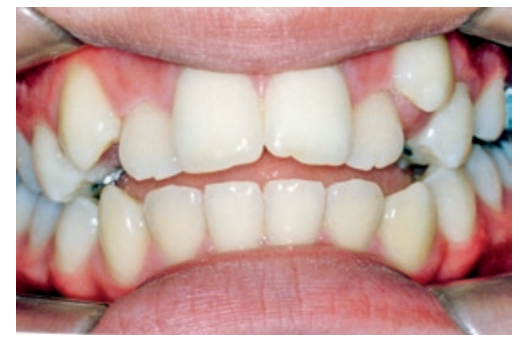

FIGURA 73 - Intrabucal com Pendulum.

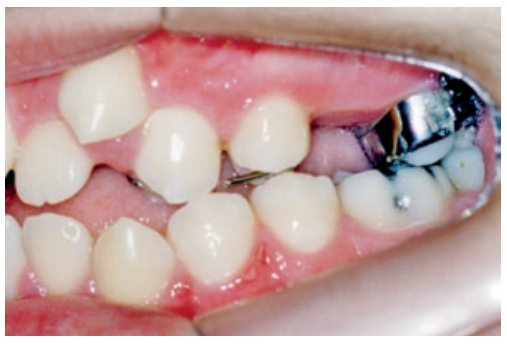

FIGURA 74 - Intrabucal com Pendulum.

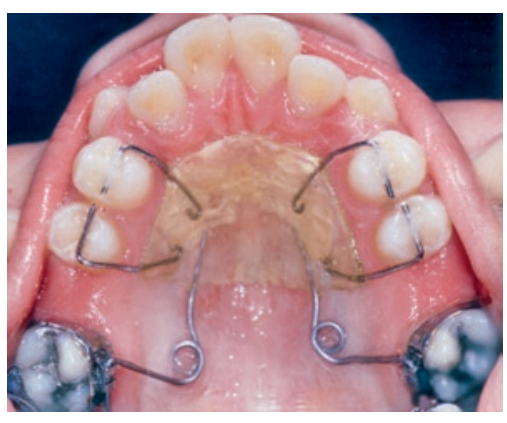

FIGURA 75 - Intrabucal com Pendulum.

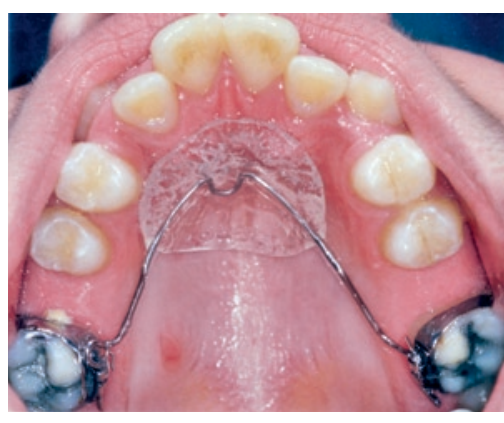

FIGURA 76 - Intrabucal com Pendulum.

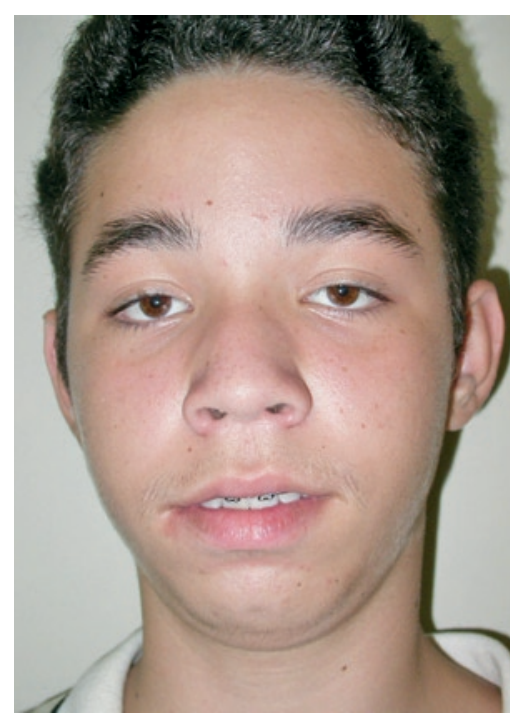

FIGURA 77 - Frontal durante nivelamento.

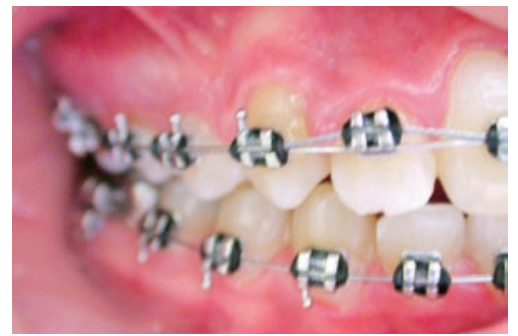

FIGURA 80 - Intrabucal direita durante nivelamento.

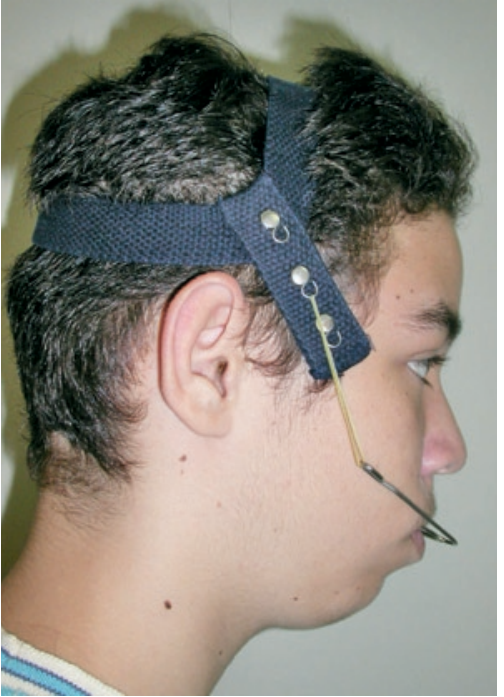

FIGURA 78 - Ancoragem com extrabucal após distalização dos molares.

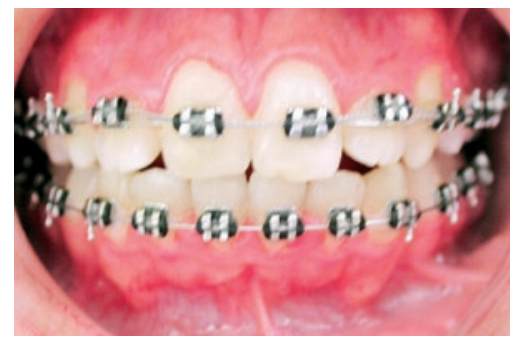

FIGURA 81 - Intrabucal frontal durante nivelamento.

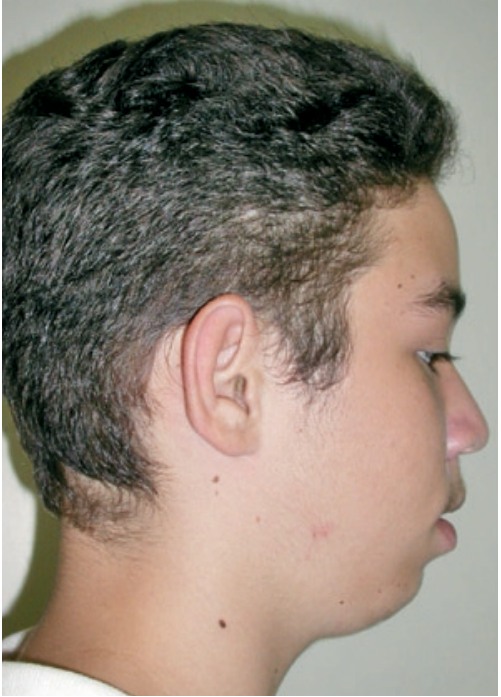

FIGURA 79 - Perfil durante o nivelamento.

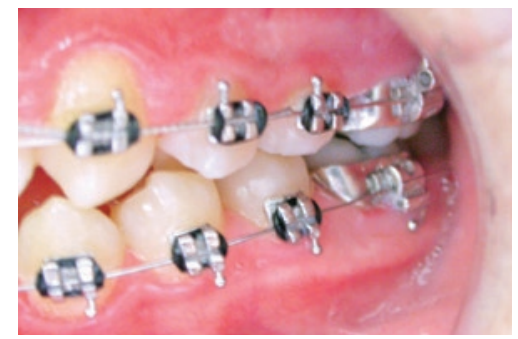

FIGURA 82 - Intrabucal esquerda durante nivelamento. 


\section{Caso 5}

\section{Dados Gerais}

A paciente A. B, 12 anos, bom estado geral de saúde, relatou queixa principal referente aos caninos vestibularizados e ao apinhamento anterior (Fig. 84).

\section{Análise Facial}

A paciente apresentava boa proporção entre os terços faciais, selamento labial, linha queixo pes- coço curta (Fig. 83, 85).

\section{Análise de Modelos}

Discrepância de $-8 \mathrm{~mm}$ no arco superior, arco inferior alinhado, ausência de overjet, sobremordida profunda (Fig. 87, 88, 89).

\section{Diagnóstico}

Má oclusão de Classe II com apinhamento na região anterior-superior.

\section{Caso 5}

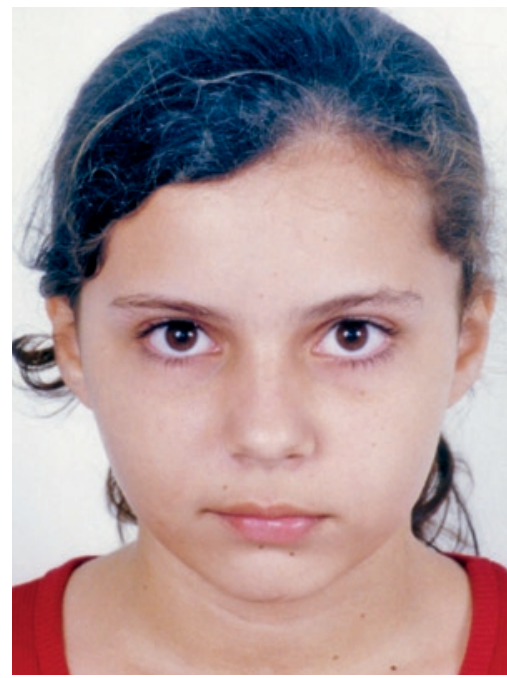

FIGURA 83 - Frontal inicial.

\section{Plano de Tratamento}

Aparelho de distalização dos molares do tipo Pendulum objetivando resolver o apinhamento anterior e a relação molar de Classe II. Ancoragem com botão de Nance e Extrabucal (Fig. 9098).

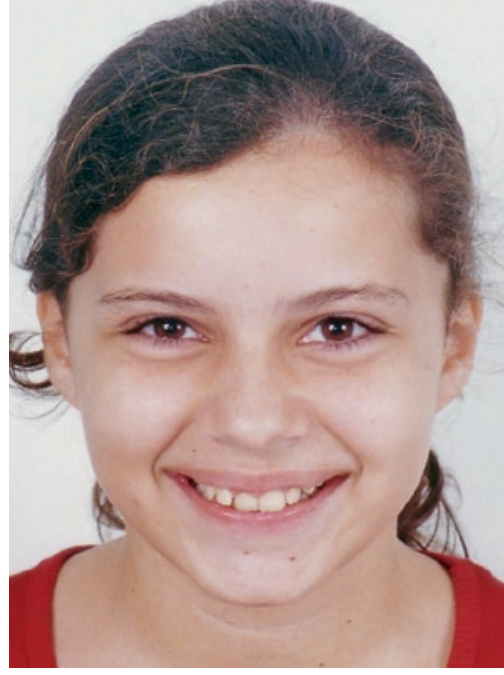

FIGURA 84 - Sorriso inicial.

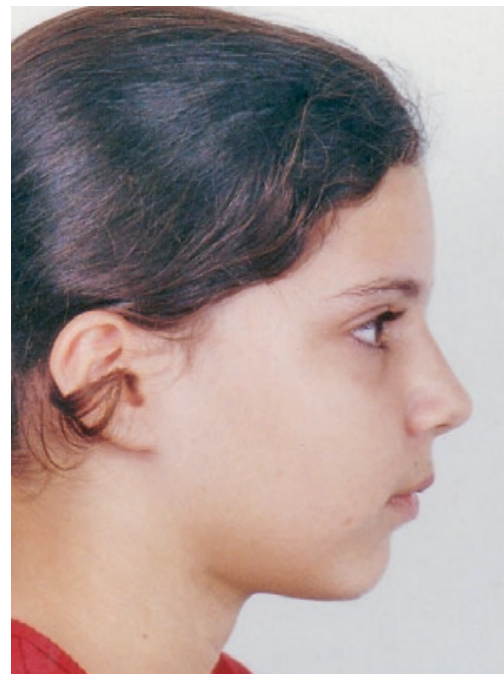

FIGURA 85 - Perfil inicial.

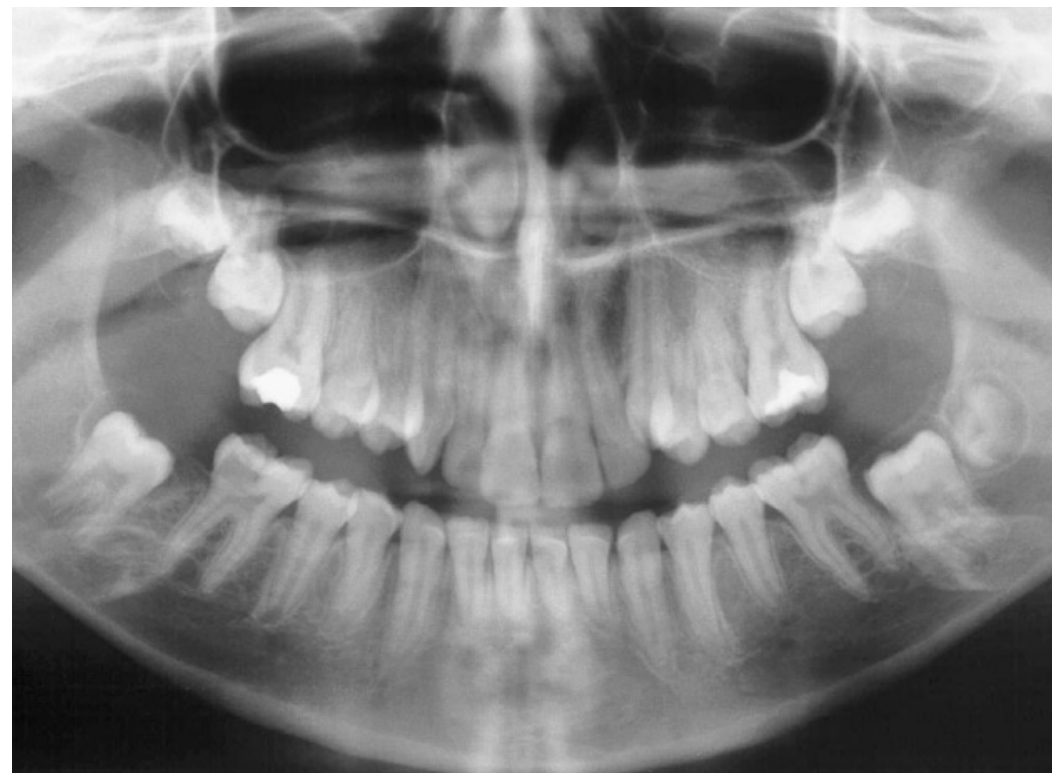

FIGURA 86 - Radiografia panorâmica inicial. 


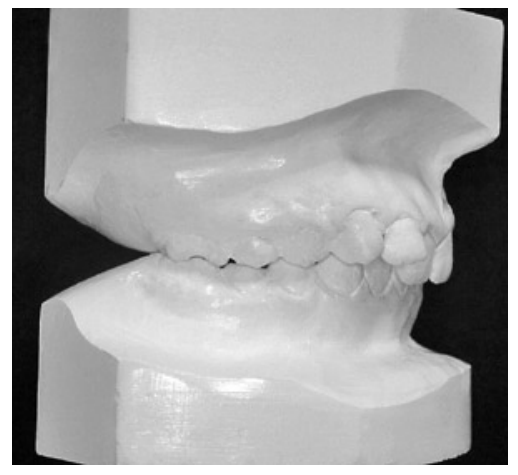

FIGURA 87 - Modelo direito inicial

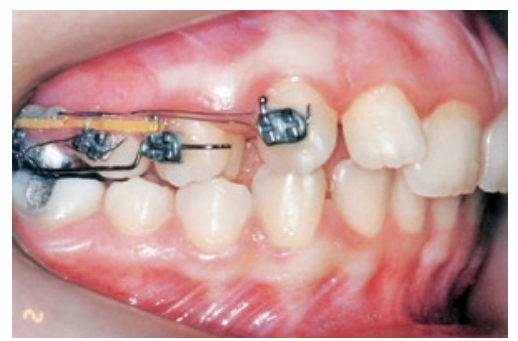

FIGURA 90 - Intrabucal direita durante a retração do canino.

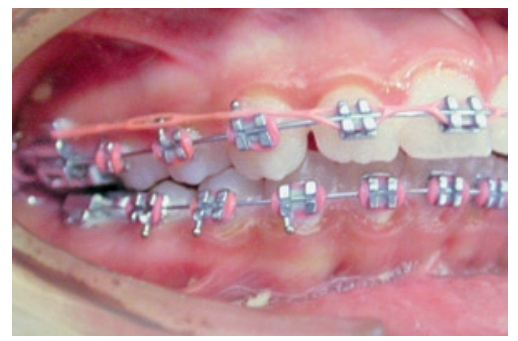

FIGURA 93 - Intrabucal direita durante nivelamento.

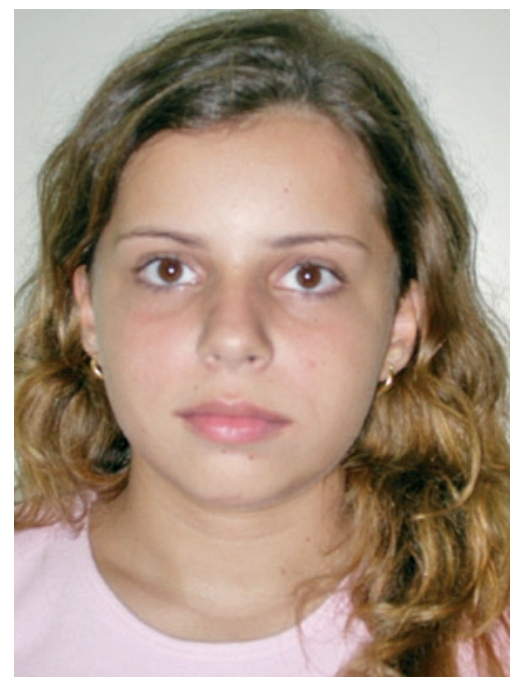

FIGURA 96 - Frontal durante nivelamento.

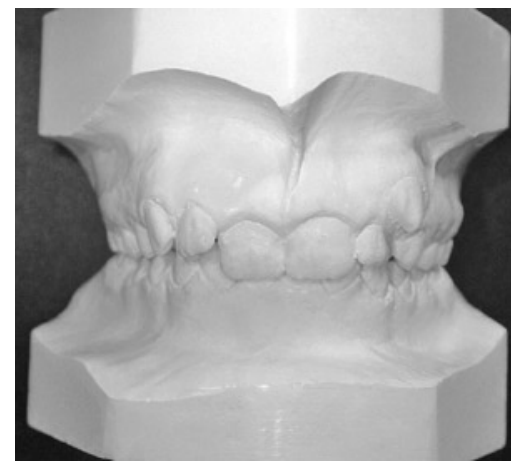

FIGURA 88 - Modelo frontal inicial.

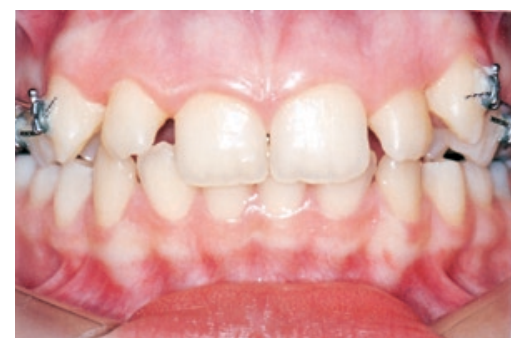

FIGURA 91 - Intrabucal frontal durante a retração do canino.

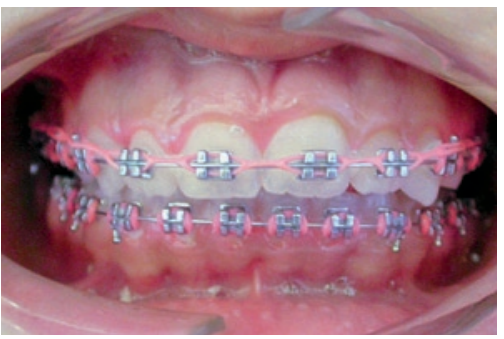

FIGURA 94 - Intrabucal frontal durante nivelamento.

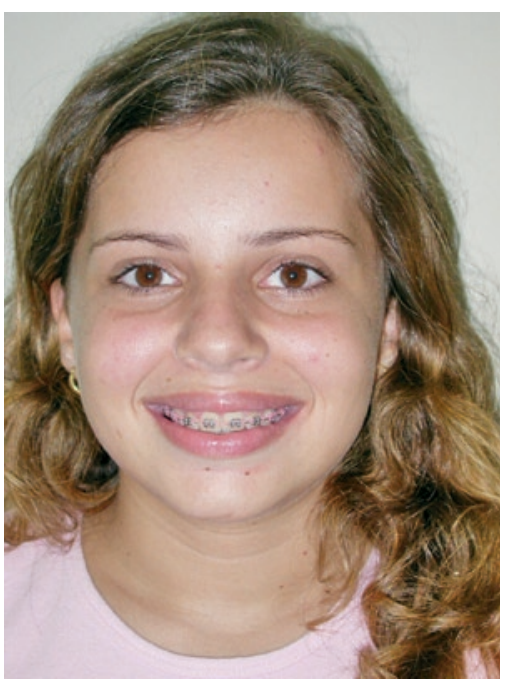

FIGURA 97 - Sorriso durante nivelamento.

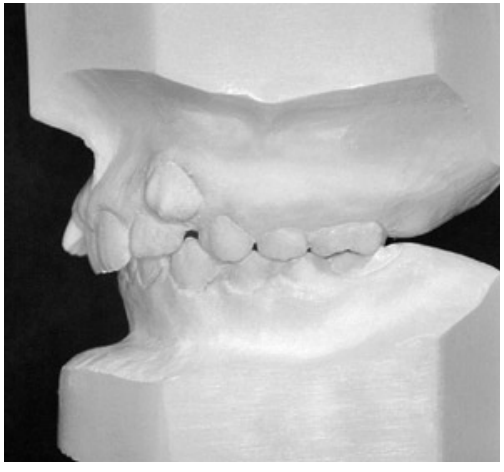

FIGURA 89 - Modelo esquerdo inicial.

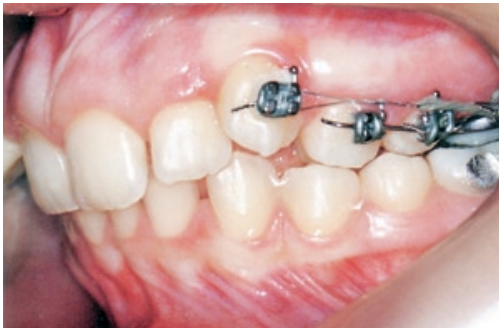

FIGURA 92 - Intrabucal esquerda durante a retração do canino.

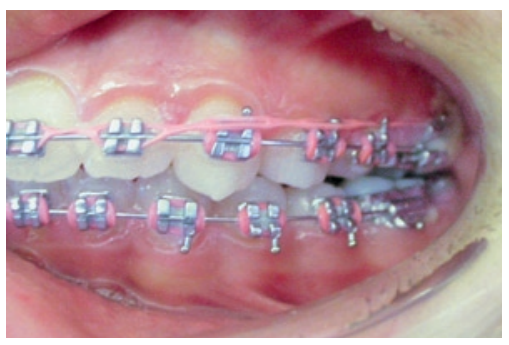

FIGURA 95 - Intrabucal esquerda durante nivelamento.

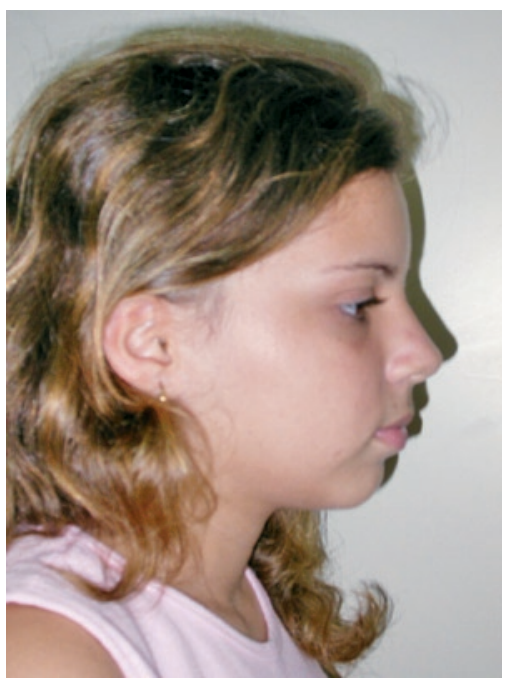

FIGURA 98 - Perfil durante o nivelamento. 


\section{Caso 6}

Dados Gerais

O paciente U. B. S., 15 anos, bom estado geral de saúde, apresentava como queixa principal os caninos vestibularizados.

\section{Análise Facial}

Em norma frontal, o paciente apresentava boa proporção entre os terços faciais, simetria facial e bom selamento labial.

No sorriso, havia o comprometimento da esté- tica facial pelos caninos mal posicionados.

$\mathrm{Na}$ análise lateral, era observado bom ângulo nasolabial, linha queixo-pescoço satisfatória. (Fig. $99,100,101)$.

\section{Exame Clínico}

O paciente apresentava má oclusão de Classe II, subdivisão direita, desvio da linha média, sobremordida profunda, apinhamento na região ânterosuperior, com falta de espaço para caninos, overjet de $5 \mathrm{~mm}$ (Fig. 102, 103, 104).

\section{Caso 6}

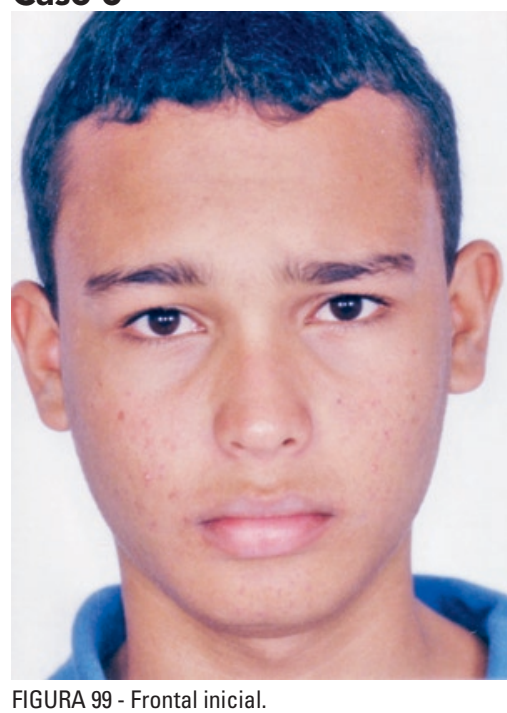

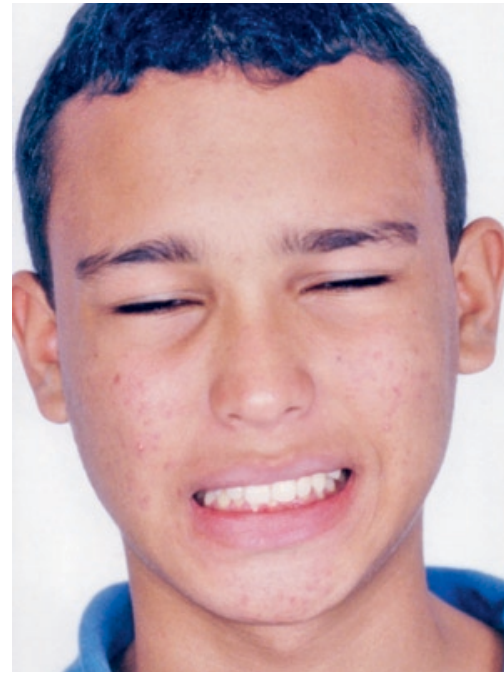

FIGURA 100 - Sorriso inicial.

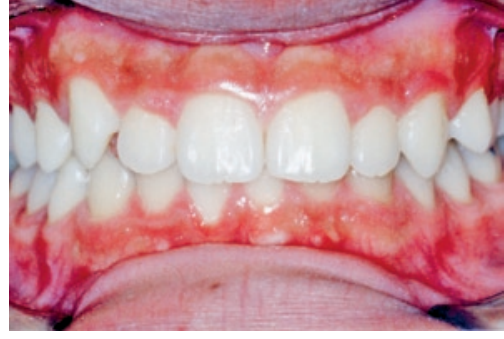

FIGURA 103 - Intrabucal frontal inicial.

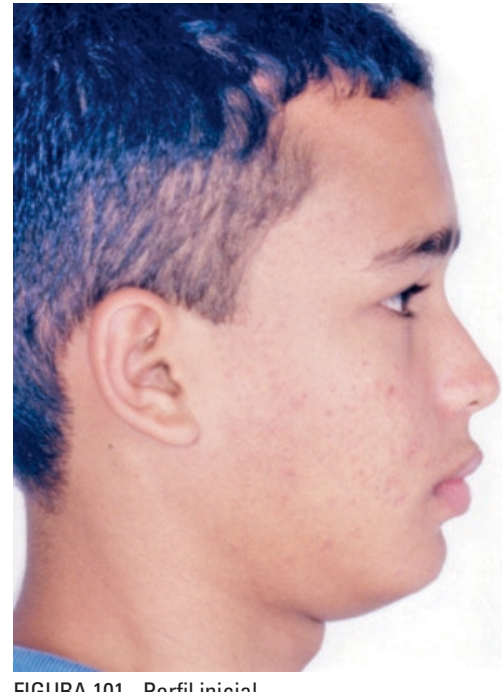

FIGURA 101 - Perfil inicial.

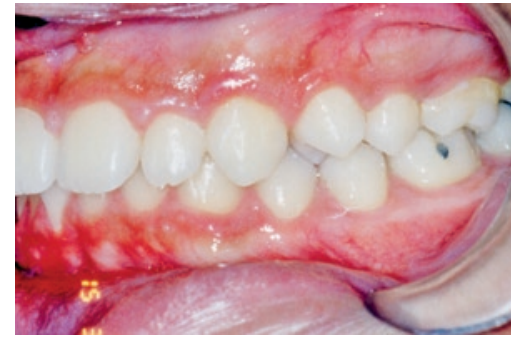

FIGURA 104 - Intrabucal esquerda inicial
FIGURA 102 - Intrabucal direita inicial.

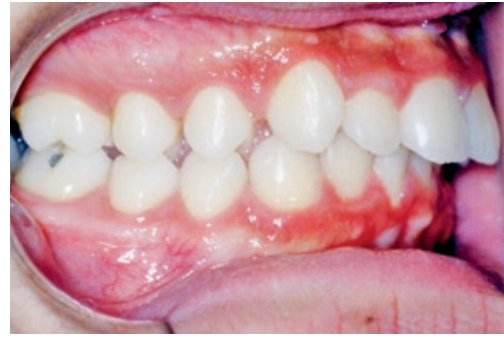

Análise Radiográfica

$\mathrm{Na}$ análise radiográfica panorâmica havia ausência de periapicopatias, os segundos molares irrompidos e os terceiros molares em rizogênese incompleta (Fig. 105).

\section{Análise de Modelos}

O paciente apresentava discrepância de modelos de $-5,8 \mathrm{~mm}$ no arco superior, caninos em infravestíbulo-versão e discreto apinhamento no arco inferior que, quando em oclusão, mostrando 
desvio da linha média e overjet $5 \mathrm{~mm}$ (Fig. 106, 107, 108).

\section{Diagnóstico}

Má oclusão de Classe II, apinhamento superior na região de caninos que se encontram em infravestíbulo-versão, sobremordida profunda, overjet de $5 \mathrm{~mm}$.

\section{Plano de Tratamento}

Foi planejado distalização dos molares, por meio do pendulum objetivando uma relação de classe I, redução do overjet. Foi utilizado como ancoragem o arco extrabucal noturno (Fig. 109-117).

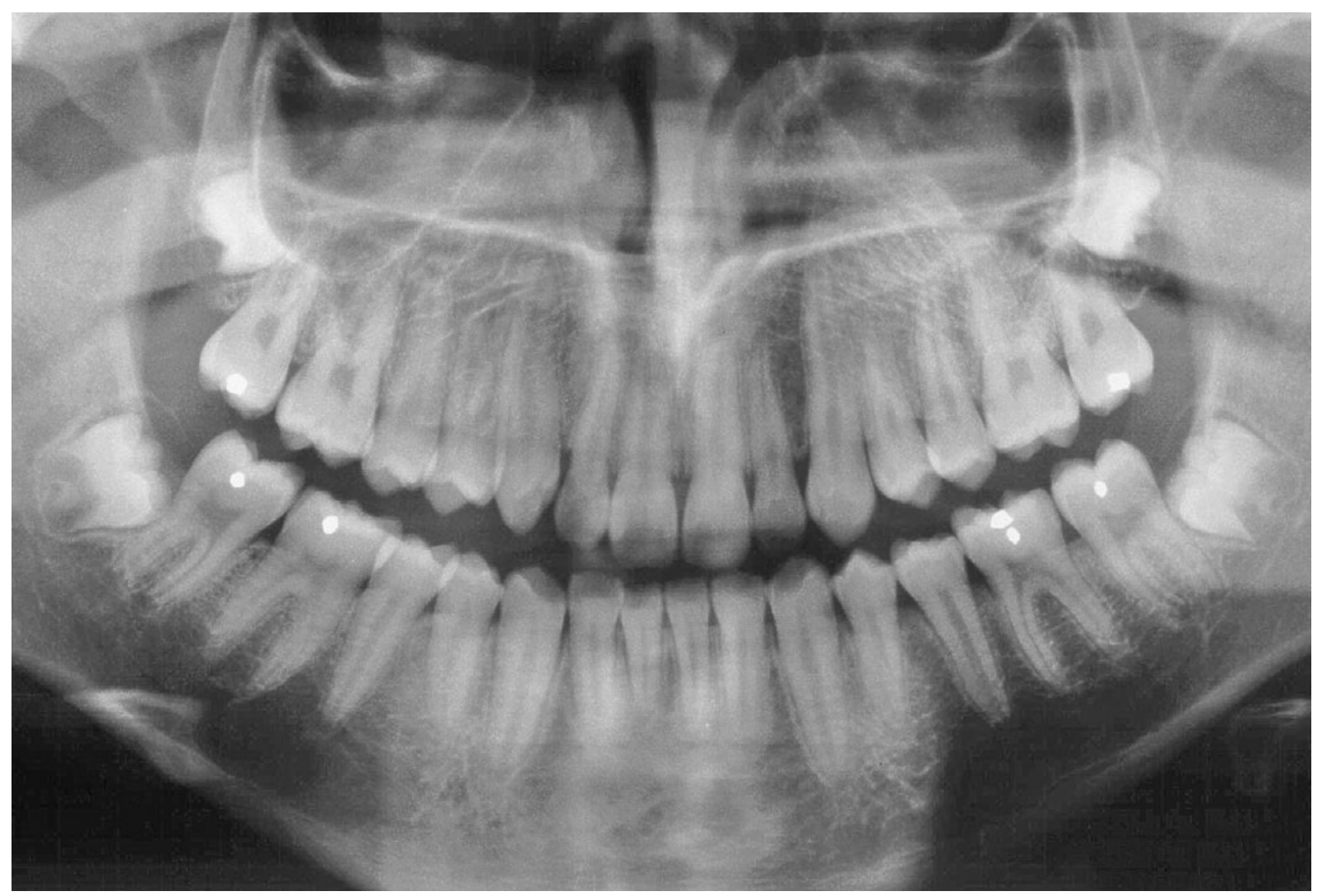

FIGURA 105 - Radiografia panorâmica inicial

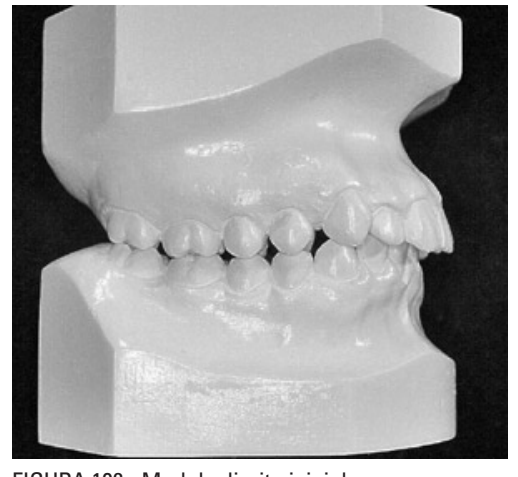

FIGURA 106 - Modelo direito inicial.

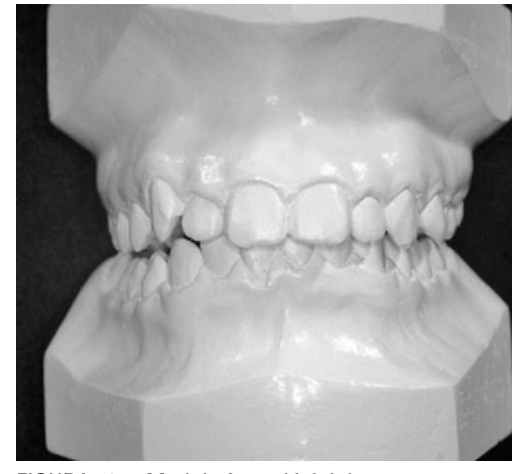

FIGURA 107 - Modelo frontal inicial.

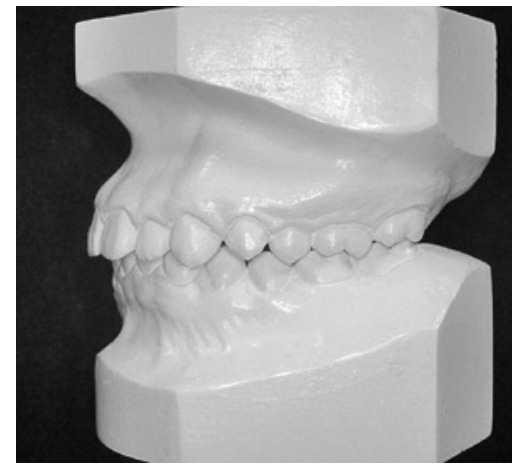

FIGURA 108 - Modelo esquerdo inicial. 


\section{Caso 7}

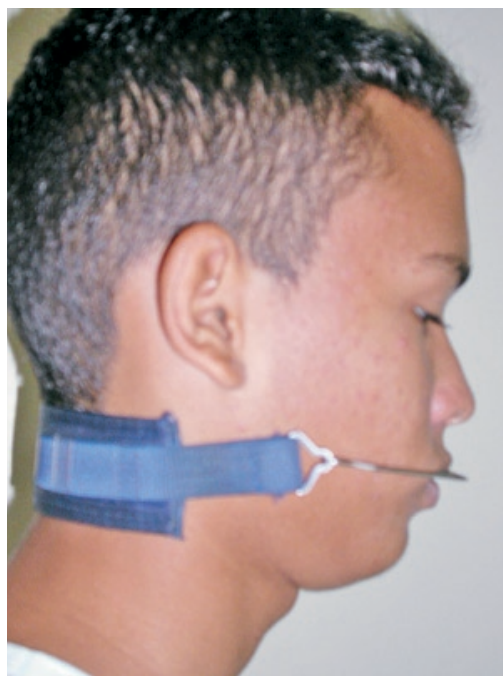

FIGURA 109 - Ancoragem com extrabucal após distalização dos molares.

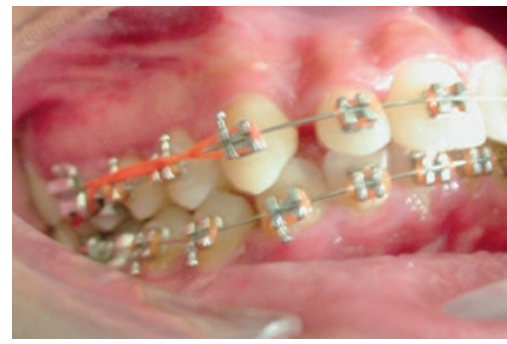

FIGURA 112 - Intrabucal direito durante a retração dos caninos.

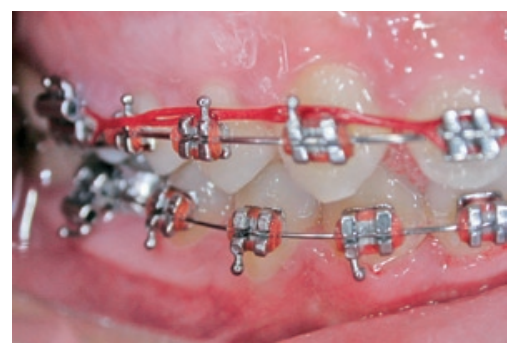

FIGURA 115 - Intrabucal direito durante nivelamento.

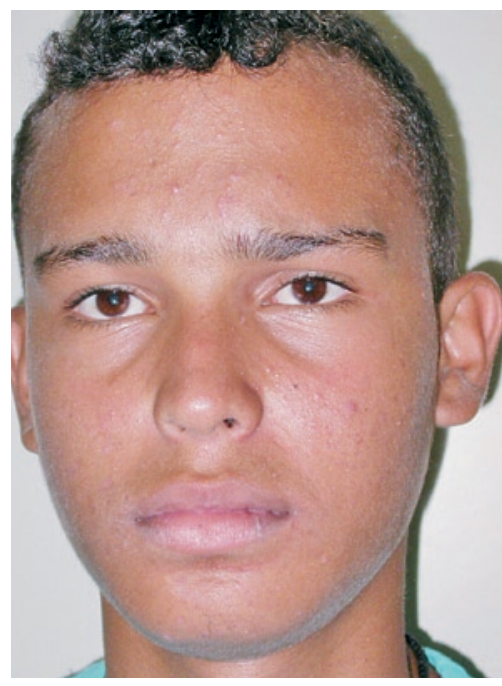

FIGURA 110 - Frontal durante nivelamento.

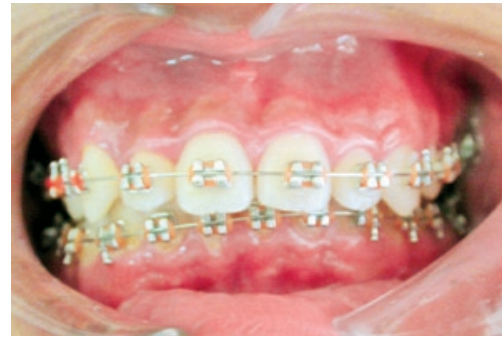

FIGURA 113 - Intrabucal frontal durante nivelamento.

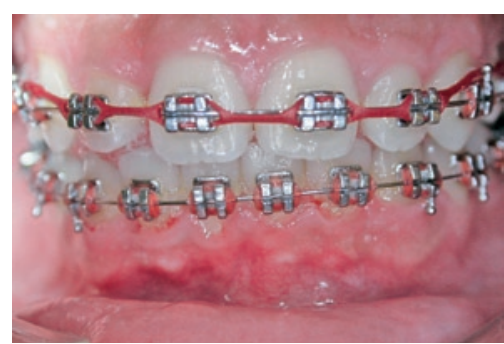

FIGURA 116 - Intrabucal frontal durante o nivelamento.

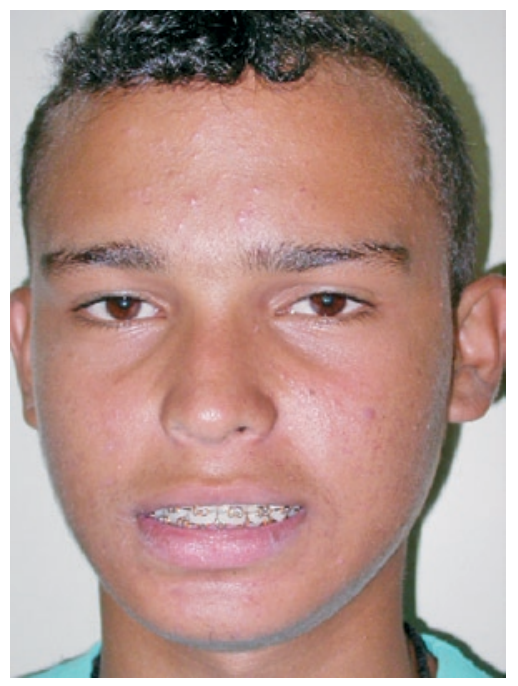

FIGURA 111 - Sorriso durante nivelamento.

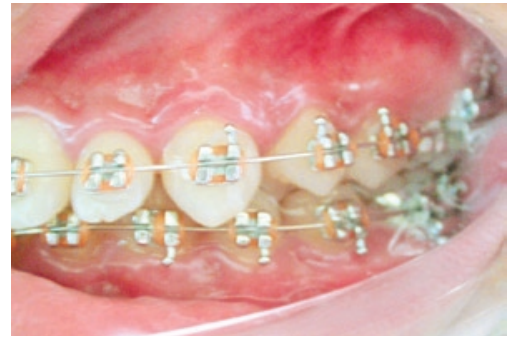

FIGURA 114 - Intrabucal esquerdo durante nivelamento.

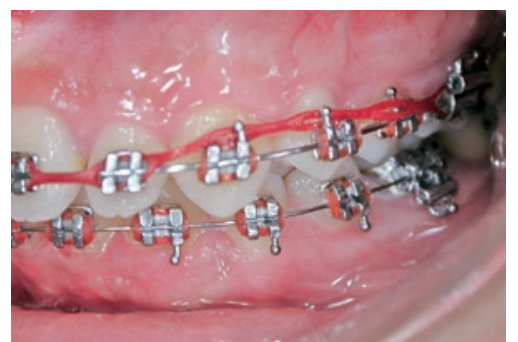

FIGURA 117 - Intrabucal esquerdo durante o nivelamento.

\section{Caso 7}

\section{Dados Gerais}

A paciente L F D, 8 anos, bom estado geral de saúde, relatou queixa principal referente à perda precoce do segundo molar decíduo superior direito, com conseqüente mesialização do molar permanente, discreta mordida aberta anterior.

\section{Análise Facial}

Em norma frontal, a paciente apresentava boa proporção entre os terços faciais, simetria facial e bom selamento labial (Fig. 118).

$\mathrm{Na}$ análise lateral, havia um bom ângulo nasolabial e linha queixo-pescoço acentuada para a idade (Fig. 120). 


\section{Exame Clínico}

A paciente apresentava uma má oclusão de Classe II dentária, sub-divisão direita, discreta mordida aberta anterior, mordida cruzada posterior esquerdo.

\section{Análise Radiográfica}

$\mathrm{Na}$ análise radiográfica panorâmica, havia ausência de periapicopatias, segundos pré-molares e caninos em erupção e os segundos molares em rizogênese incompleta (Fig. 124).

\section{Análise de Modelos}

A paciente apresentava discrepância de modelos de $-5 \mathrm{~mm}$ no arco superior, mordida cruzada unilateral (Fig. 125, 126, 127).

\section{Diagnóstico}

Tendência a Classe III esquelética, Classe II dentária direita, discreta mordida aberta anterior.

\section{Plano de Tratamento}

Foi planejado aparelho tipo Haas objetivando descruzar a mordida posterior, distalização do molar direito, através do pendulum objetivando uma relação de Classe I, e obtenção de espaço para erupção do segundo pré-molar impactado. Placa para estabilização dos molares distalizados, alinhamento e nivelamento dos arcos dentários. (Fig. 128-135).
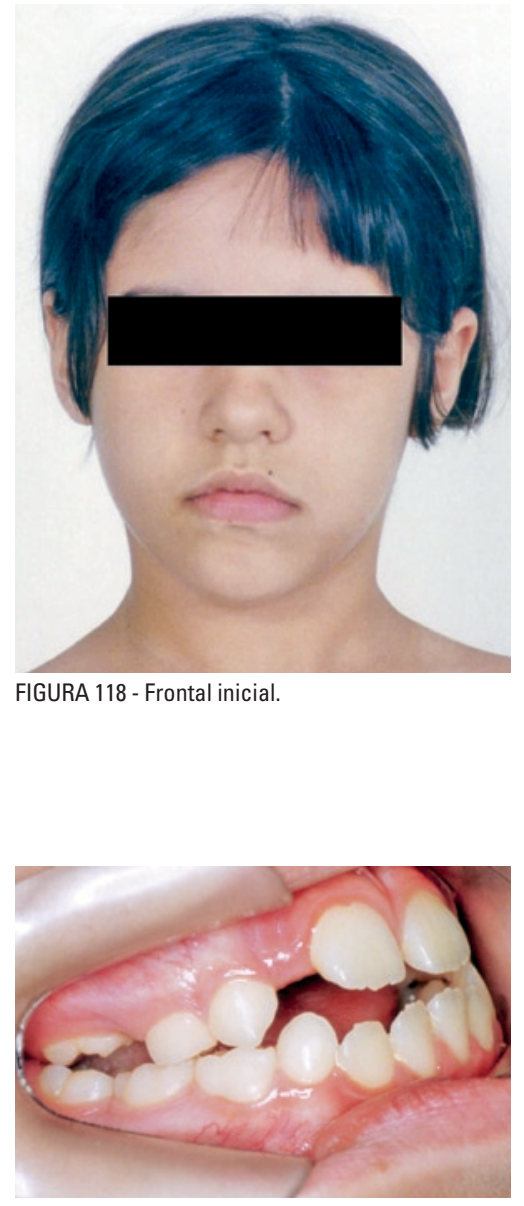

FIGURA 121 - Intrabucal direita inicial.

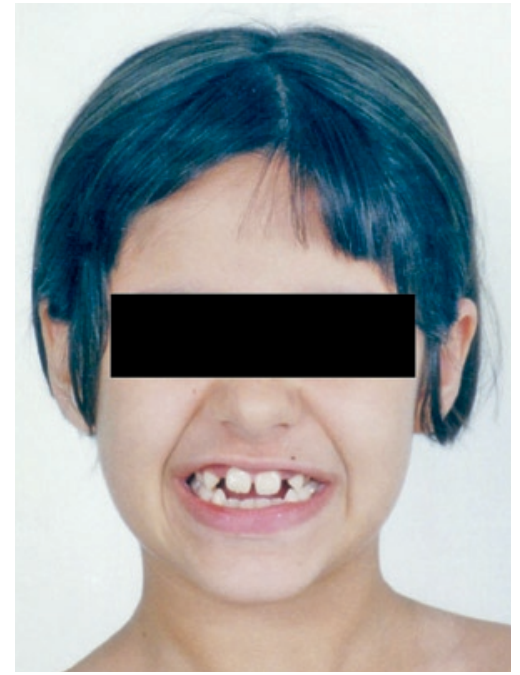

FIGURA 119 - Sorriso inicial.

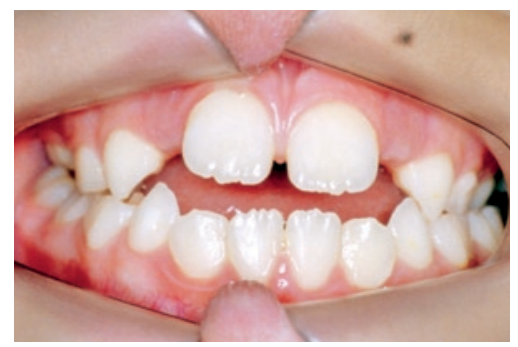

FIGURA 122 - Intrabucal frontal inicial.

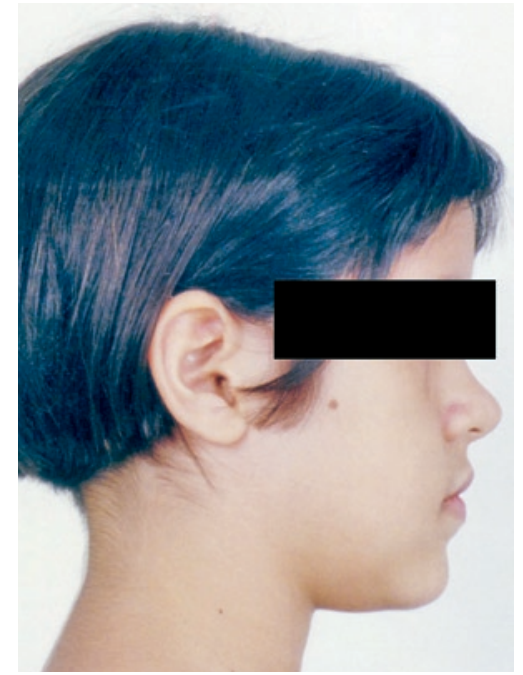

FIGURA 120 - Perfil inicial.

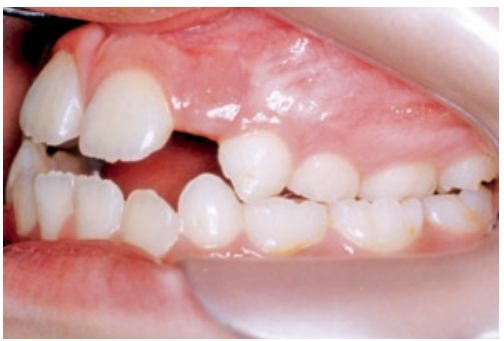

FIGURA 123 - Intrabucal esquerda inicial. 


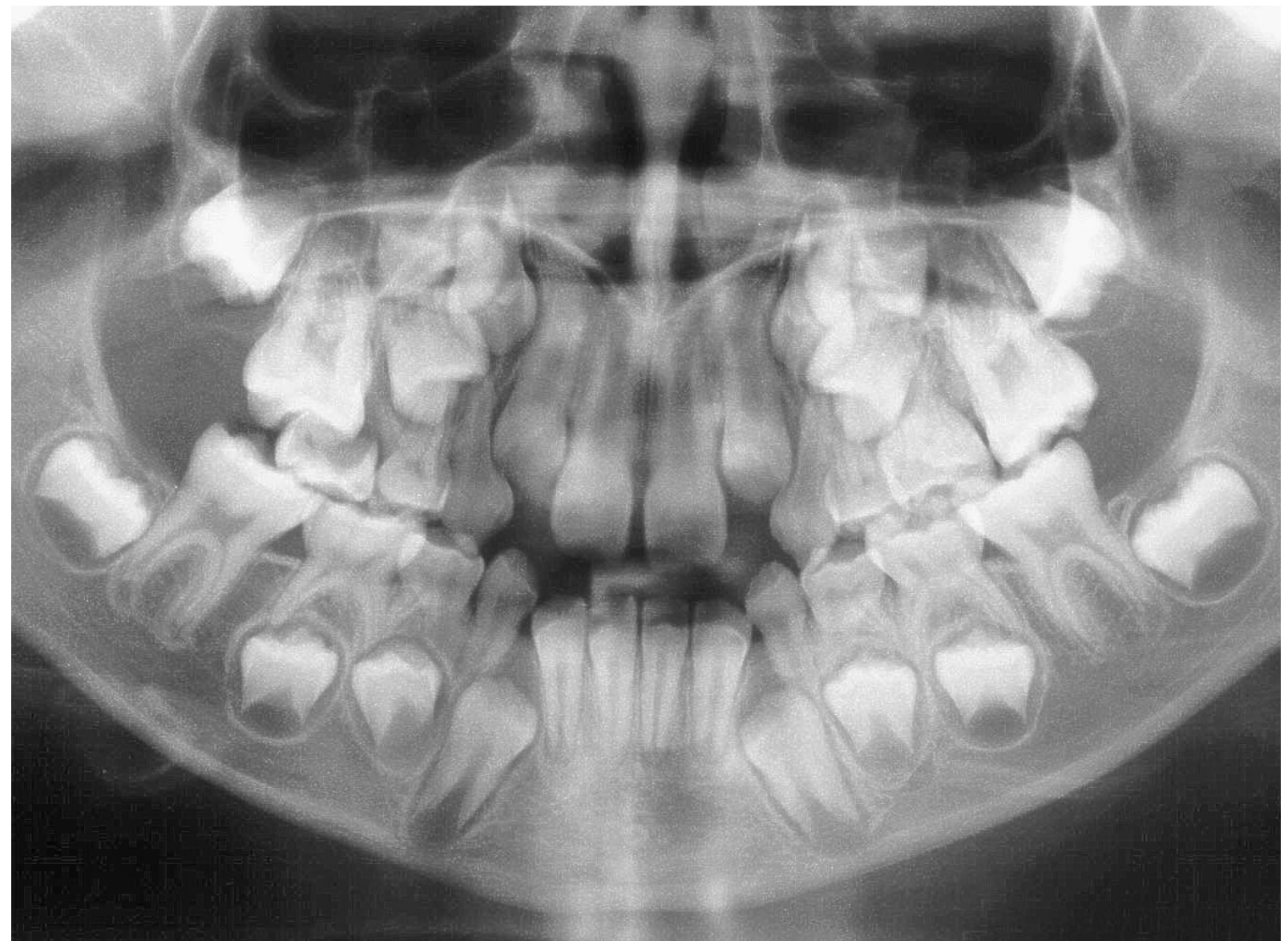

FIGURA 124 - Radiografia panorâmica inicial.

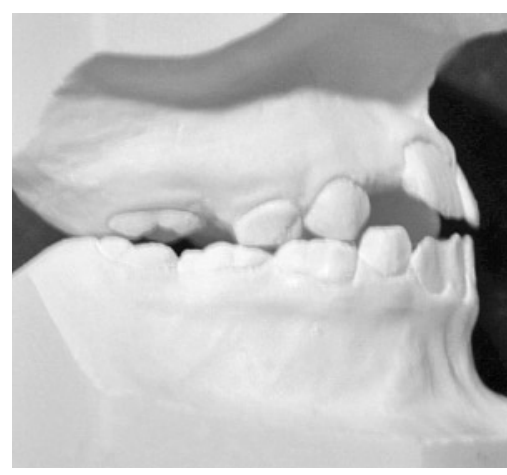

FIGURA 125 - Modelo direito inicial.

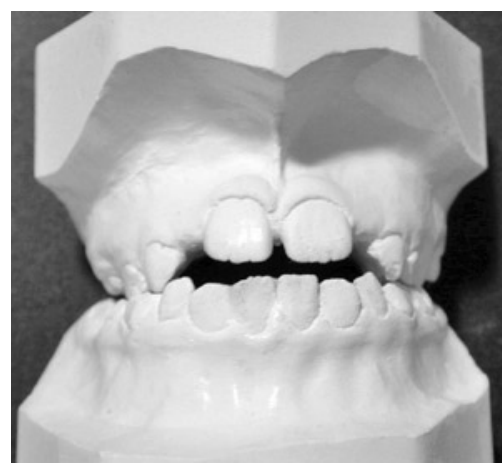

FIGURA 126 - Modelo frontal inicial.

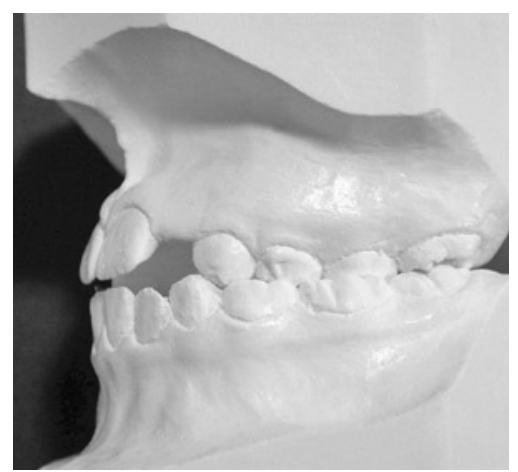

FIGURA 127 - Modelo esquerdo inicial (mesialização do molar) 


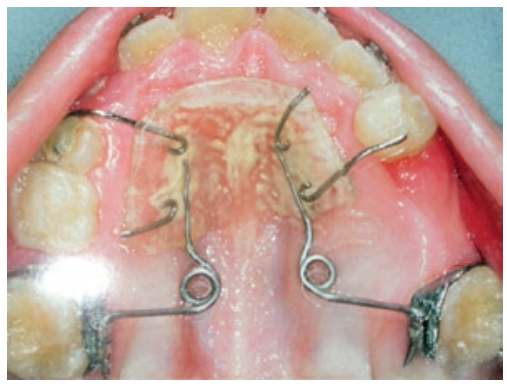

FIGURA 128 - Placa de estabilização após a distalização.

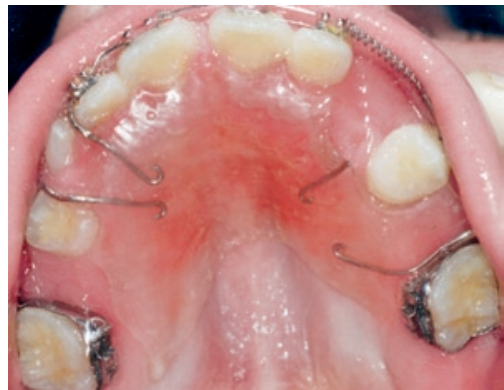

FIGURA 129 - Oclusal após a distalização dos molares.

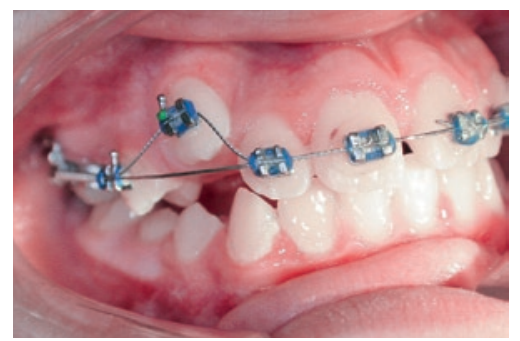

FIGURA 130 - Direita durante o nivelamento.

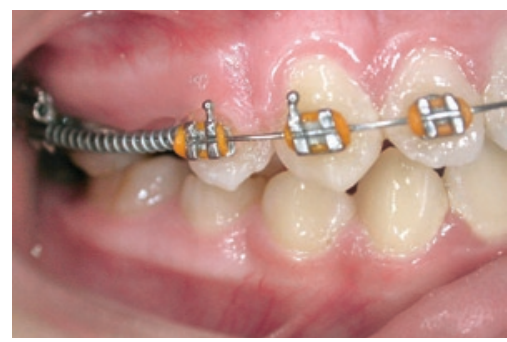

FIGURA 133 - Direita durante o nivelamento

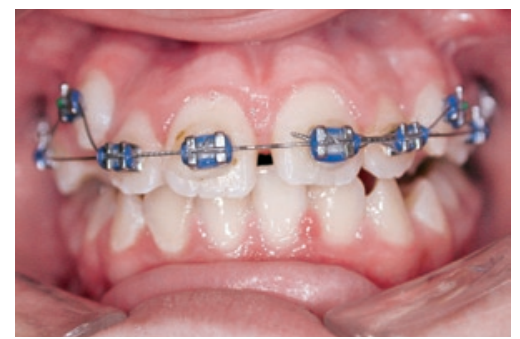

FIGURA 131 - Frontal durante o nivelamento.

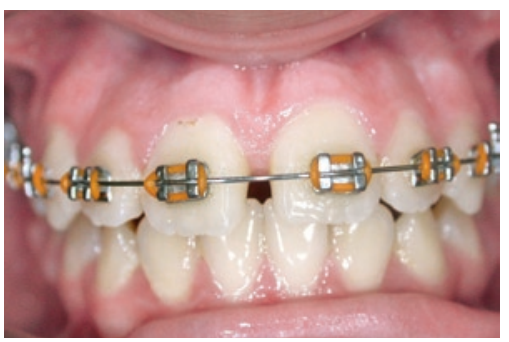

FIGURA 134 - Frontal durante o nivelamento

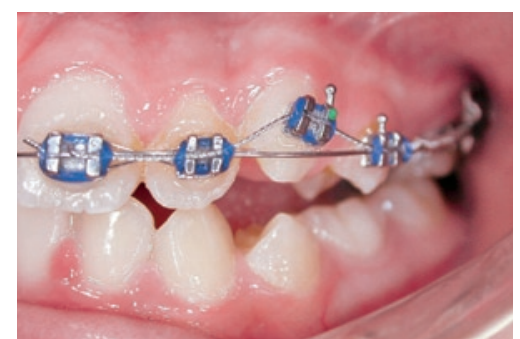

FIGURA 132 - Esquerda durante o nivelamento.

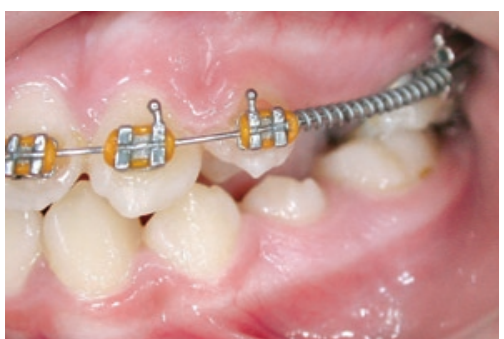

FIGURA 135 - Esquerda durante o nivelamento

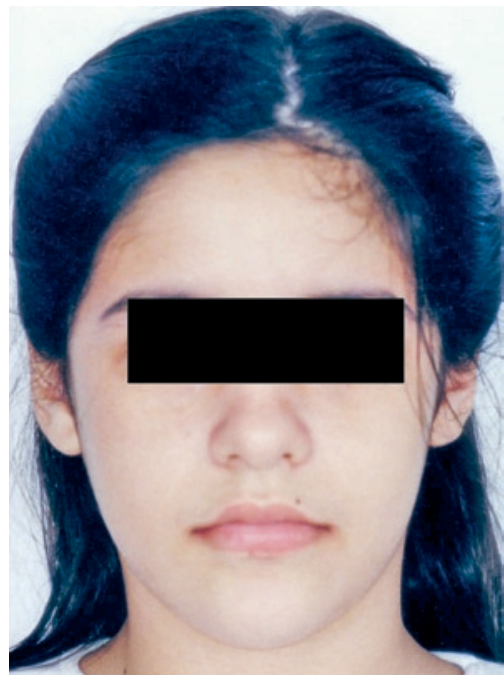

FIGURA 136 - Frontal após a distalização.

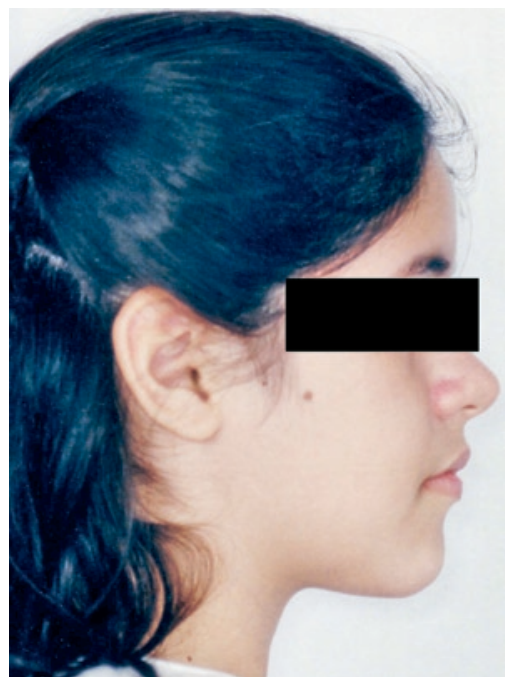

FIGURA 137 - Perfil após a distalização. 


\section{CONCLUSÃO}

O pêndulo idealizado por Hilgers mostrou-se bastante eficiente na correção da Classe II dentária e na obtenção de espaços para o alinhamento do arco, sem exigir total colaboração do paciente ao seu uso. No entanto é importante ressaltar a dificuldade na higienização e a possibilidade de fraturas do aparelho.
Seu mecanismo de ação é bastante simples e se dá basicamente pela ativação das molas de TMA. É importante ressaltar que a eficácia do seu uso está diretamente relacionado a um planejamento correto onde fatores como grau de discrepância dentária, inclinação axial dos molares e padrão facial devem ser respeitados.

\title{
Pendulum: molar distalization with simplicity on its making and utilization
}

\begin{abstract}
Over the time, the correction of Class II has been based on the use of anchorage extraoral traction with the headgear. Nowadays, many devices have been used to give the possibility of distalization of the maxillary permanents molars. One of these devices is the, appliance Pendulum suggested by Hilgers. This device also requires a minimum of the patient's cooperation; considering that the lack of the patient's cooperation can compromise the careful elaborated treatment plan. The aim of work is to describe the characteristic, the way of making and the indication of the Pendulum, based on case illustrations practices medicine.
\end{abstract}

Key words: Orthodontic treatment. Molar distalization. Hilgers' Pendulum.

\section{REFERÊNCIAS}

1. ALMEIDA, R. R. et al. Modificação do aparelho pendulum / pend $-x_{\text {; }}$ descrição do aparelho e técnica de construção. $\mathbf{R}$ Dental Press Ortodon Ortop Facial, Maringá, v. 4, no. 6 p. 12-19, nov./ dez. 1999.

2. BONDEMARK, L.; KUROL, J.; BERNHOLD, M. Repelling magnets versus superlastic nickel titanium coils simultaneous distal movement of maxillary first and second molars. Angle Orthod, Appleton, v. 64, p. 189-198, 1994

3. BYLOFF, F. K; DARENDELILER, M. A. Distal molar movement using the pendulum appliance. Part II: the effects of maxillary molar root upringhting bends. Angle Orthod, Appleton, v. 67, no. 4, p. 261-270, 1997

4. CARANO, A.; TESTA, M. The distal jet for upper molar distalization. J Clin Orthod, Boulder, v. 30, p. 374-390, 1996.

5. CETLIN, N. M.; TEN HOEVE, A. No extraction Treatment. J Clin Orthod, Boulder, v.17, p. 336-413, 1983

6. EVERDI, N.; KOYUTURK, Ö.; KUÇUKKELES, N. Nickel-Titanium coils and repelling magnets: comparison of two different intra-oral molar distalization techniques. Br J Orthod, London, v. 24, p. 47-53, 1997.

7. GIANELLY, A. A. et al. The use of magnets to move molars distally. Am J Orthod, St. Louis, v. 96, p. 161-167, 1989.

8. GHOSH, J.; NANDA, R. S. Evaluation of an intraoral maxillary molar distalization technique. Am J Orthod, St. Louis, v.110, p. 639-646, 1996.

9. HILGERS, J. J. the pendulum appliance for class II non-compliance therapy. J Clin Orthod, Boulder, v. 26, no.11, p. 706714, nov. 1992.

10. $\mathrm{ITOH}, \mathrm{T}$. et al. Molar distalization with repelling magnets. J Clin Orthod, Boulder, v. 25, no.10, p. 611-617, Oct. 1991.

11. JONES, R.; WHITE, J. M. Rapid class II molar correction with an open coil jig. J Clin Orthod, Boulder, v. 2, p. 661-664, 1992.
12. LITTLE, R. M.; WALLEN, T. R.; RIEDEL, R. A. Stability and relapse of mandible anterior an alignment: first premolar extraction cases treated by traditional edgewise orthodontics. Am J Orthod St. Louis, no. 80, p. 349-364, 1981.

13. LOCATELLI, R. et al. Molar distalization with super elastic Niti Wire. J Clin Orthod, Boulder, v. 26, p. 277- 279, 1992.

14. MARTINS, J. C. R. et al. Pendex modificado: um novo aparelho para distalização dos molares superiores no tratamento da má oclusão de classe II. J Bras Ortodon Ortop Maxilar, Curitiba v. 1, p. 37-43, 1996

15. NANDA, R. S. KIERL, M. J Prediction of cooperation in orthodontic treatment. Am J Orthod Dentofacial Orthop, St. Louis v. 102, p. 15-21, 1992.

16. PECK, H.; PECK, S. A . A concept of facial esthetics. Angle Orthod, Appleton, no. 4, p. 284-317, 1970.

17. PROFFIT, W. R.; FIELDS, H. W. Contemporary orthodontics. 3rd ed. St. Louis: C. V. Mosby, c2000. p. 742.

18. SNODGRASS, D. J, A fixed appliance for maxillary expansion, molar rotation, and molar distalization. J Clin Orthod. Boulder, v. 30 no. 3, p. 156-159, Mar. 1996.

19. SUGUINO, R.; FURQUIM, L. Z.; RAMOS, A . L. O Aparelho Jones Jig. R Dental Press Ortodon Ortop Facial, Maringá, v. 5, n. 3 p. 83-116, 2000.

\section{Endereço para correspondência}

Mêrian Lucena M. Leiros

Rua Mipibu, 360 - Petrópolis

CEP: 59020-250 - Natal - RN

E-mail: merian@digi.com.br 